\title{
Archaeal and bacterial assemblages in the Oxygen Minimum Zone of the upwelling ecosystem off Central Chile as determined by organic biomarkers
}

\section{Ensambles de arqueas y bacterias en la Zona de Mínimo Oxígeno del ecosistema de surgencia de Chile central determinados mediante biomarcadores orgánicos}

\author{
Benjamín Srain ${ }^{1}$, Julio Sepúlveda ${ }^{2}$, Silvio Pantoja ${ }^{3 *}$, Roger E. Summons ${ }^{2}$, Renato A. Quiñones ${ }^{4} \&$ \\ HÉCTOR A. LEVIPAN ${ }^{1,5}$ \\ ${ }^{1}$ Graduate Program in Oceanography, Department of Oceanography, University of Concepción, Concepción, Chile. \\ ${ }^{2}$ Department of Earth, Atmospheric, and Planetary Sciences, Massachusetts Institute of Technology, Cambridge, USA. \\ ${ }^{3}$ Department of Oceanography and Program COPAS Sur-Austral, University of Concepción, Concepción, Chile. \\ ${ }^{4}$ Department of Oceanography and Interdisciplinary Center for Aquaculture Research (INCAR), University of Concepción, \\ Concepción, Chile. \\ ${ }^{5}$ Centro de Investigación Marina Quintay (CIMARQ), Facultad de Ecología y Recursos Naturales, Universidad Andrés Bello, \\ Valparaíso, Chile. \\ *spantoja@udec.cl (S. Pantoja)
}

\begin{abstract}
Organic biomarkers were used to investigate the influence of seasonal changes in oxygenation and water chemistry on the distribution of archaea and bacteria in the water column and surface sediments of the continental shelf off central Chile $\left(\mathrm{ca} .36^{\circ} \mathrm{S}\right)$, an area influenced by seasonal upwelling and the development of an oxygen minimum zone. We were interested in establishing if occurrence of archaea and bacteria responds to oxygenation and water chemistry for which we analyzed archaeal isoprenoid (i) and bacterial branched (br) glycerol dialkyl glycerol tetraethers (GDGTs). Our results combined with molecular data from a year round observational program at the same sampling site and depths indicatives the occurrence and dominance of the marine pelagic group Thaumarchaeota. Changes in the distribution of iGDGTs might be explained by (i) the presence of archaeal populations in sub-oxic waters, phylogenetically different from those in surface water, (ii) changes in the relative contribution of Euryarchaeota with depth, and (iii) a relationship between Thaumarchaeota and environmental factors other than temperature. Branched GDGTs were more abundant in the upper, oxic layer during the non-upwelling season, may be a result of higher river runoff, whereas their diversity was higher within sub-oxic waters. Our results indicate a vertical segregation of iGDGTs and brGDGTs, with predominance of archaeal biomarkers during the low productivity season.
\end{abstract}

KeYwords: Glycerol dialkyl glycerol tetraethers (GDGTs), archaea, bacteria, oxygen minimum zone, upwelling, Chile.

\section{RESUMEN}

Se utilizaron biomarcadores orgánicos en para investigar la influencia de cambios estacionales en los niveles de oxigenación y la química del agua sobre la distribución de arqueas y bacterias en la columna de agua y los sedimentos superficiales de la plataforma continental frente a Chile central, un área influenciada por surgencia estacional asociada al desarrollo de una zona de mínimo oxígeno. Nuestro interés es establecer si la ocurrencia de arquea y bacteria responde a la oxigenación y química del agua para lo cual analizamos gliceroles dialquil gliceroles tetra-éteres (GDGTs) isoprenoides arqueanos (i) y ramificados bacterianos (r). Nuestros resultados, combinados con datos moleculares de observaciones durante un año en el mismo lugar y profundidades del sitio de estudio indican la presencia y dominancia del grupo arqueano marinopelágico Thaumarchaeota. Los cambios observados en la distribución de iGDGTs podrían explicarse por (i) la presencia de poblaciones de arqueas marinas en la capa de agua sub-óxica, filogenéticamente diferentes a las de aguas superficiales, (ii) cambio en la contribución relativa de Euryarchaeota con profundidad, y (iii) una relación entre Thaumarchaeota y factores ambientales distintos a la temperatura. Los GDGTs ramificados fueron más abundantes en la capa óxica superior durante el periodo de no-surgencia, tal vez influenciado por la alta descarga de ríos, mientras que su diversidad fue más alta en el agua sub-óxica. Nuestros resultados indican una segregación vertical de los GDGTs isoprenoides y ramificados, con el predominio de biomarcadores arqueanos durante el periodo de baja productividad.

Palabras clave: Glicerol dialquil glicerol tetraéteres (GDGTs), arquea, bacteria, zona de mínimo de oxígeno, surgencia, Chile. 


\section{INTRODUCTION}

Isoprenoid (i) and branched (br) glycerol dialkyl glycerol tetraethers (GDGTs) are cell membrane lipids diagnostic of archaea and bacteria, respectively (Langworthy et al. 1983; Hoefs et al. 1997; Hopmans et al. 2004; Zhou et al. 2011; Fietz et al. 2012). These biomarkers have been increasingly used to investigate microbial diversity, biogeochemistry, and terrestrial input into contemporaneous and ancient aquatic systems, as well as for reconstructions of past ocean temperatures by using the $\mathrm{TEX}_{86}$ index (Kuypers et al. 2001; Schouten et al. 2002; Blumenberg et al. 2004; Hopmans et al. 2004; Herfort et al. 2006; Kim et al. 2010; Schouten et al. 2013; Pearson \& Ingalls 2013). Archaeal iGDGTs are ubiquitous in marine and freshwater and sediments, as well as in soils (Schouten et al. 2000; Wuchter et al. 2005, Sinninghe Damsté et al. 2012). In the marine realm, GDGTs have been suggested to derive mostly from planktonic Thaumarcheota (De Long et al. 1998; Schouten et al. 2000; Sinninghe Damsté et al. 2002a, 2002b; Wuchter et al. 2005; Turich et al. 2007; Pitcher et al.2011a), although a contribution from planktonic euryarchaeota and benthic archaea cannot be excluded (Pearson \& Ingalls 2013; Lincoln et al. 2014). Core archaeal lipids comprise a diverse group of compounds, including dialkyl glycerol diethers (DGDs), isoprenoid glycerol dialkanol diethers (iGDDs) and iGDGTs containing between 0 and up to 8 cyclopentane moeties and, in the case of crenarchaeol, four pentacyclic moieties and one cyclohexane moiety (Langworthy et al. 1972; Kates 1992; Gambacorta et al. 1994; Schleper et al. 1995; De Rosa 1996; Swain et al. 1997; Shimada et al. 2002; Macalady et al. 2004; Schouten et al. 2007; Liu et al. 2012; Schouten et al. 2013).

The most common iGDGTs in marine environments are the acyclic GDGT-0 and crenarchaeol (Nishihara et al. 1987; Schouten et al. 2000; Sinninghe Damsté et al. 2000; Turich et al. 2007). Although GDGTs 1-4 have been found in enrichment cultures and pure cultures of marine archaea (Wuchter et al. 2004; De la Torre et al. 2008; Schouten et al. 2008; Pitcher et al. 2010), they comprise a minor proportion of the GDGT pool found in marine particulate matter and sediments (Schouten et al. 2000; Schouten et al. 2002; Pitcher et al. 2011b).

Archaea were originally thought to inhabit extreme environments such as those characterized by high salinity, high temperature, or anoxia (Woese et al. 1978; De Rosa \& Gambacorta 1988; De Long 2003). However, nonextremophilic archaea are ubiquitous and abundant in oceanic (Fuhrman 1992; DeLong et al. 1994; Murray et al. 1999; Karner et al. 2001) and coastal (DeLong 1992; Murray et al. 1998a; Pernthaler et al. 2002; Levipan et al. 2007a; Quiñones et al. 2009) regions. The distribution of genes markers and membrane lipids indicates that marine Thaumarchaeota (formerly Marine Group 1 Crenarchaeota, Brochier-Armanet et al. 2008) are ubiquitous in both epipelagic and mesopelagic areas of the water column, although they are more abundant in subsurface water near the base of the photic zone (Sinninghe Damsté et al. 2002a, 2002b; Herndl et al. 2005; Wuchter et al. 2005; Levipan et al. 2007a; 2007b; Turich et al. 2007; Quiñones et al. 2009; Pitcher et al. 2011b). Euryarchaeota also occur in surface, mesopelagic and deep waters, although generally in lower abundances compared to Thaumarchaeota (Massana et al. 1997; Lopez- Garcia et al. 2001; Bano et al. 2004; Moreira et al. 2004).

Since brGDGTs have been shown to be ubiquitous in peat and soil (Schouten et al. 2000; Sinninghe Damsté et al. 2000; Hopmans et al. 2004; Weijers et al. 2006, 2007; Huguet et al. 2010a) as well as in marine and lacustrine environments influenced by terrestrial input (Schouten et al. 2007; Belicka \& Harvey 2009; Blaga et al. 2009; Kim et al. 2009; Powers et al. 2010), it is thought that soil bacteria synthesize brGDGTs. However only one brGDGT (brGDGT-I; Fig. 3i) has been identified in two cultures of anaerobic acidobacteria (Sinninghe Damsté et al. 2011). Since high concentrations of brGDGTs are found in suboxic-anoxic aquatic environments, it is likely that they are also synthesized by other groups of bacteria (Sinninghe Damsté et al. 2011).

iGDGTs are more abundant in sub-surface oxic water (Huguet et al. 2007; Ingalls et al. 2012), as well as in suboxic water, such as the Arabian Sea (Sinninghe Damsté et al. 2002a, 2002b), Black Sea (King et al. 1998; Wakeham et al. 2007), Cariaco Basin (Wakeham et al. 2004, 2012), and the eastern tropical North Pacific (Xie 2013). In these areas, oxygen minimum zones are characterized by dissolved oxygen concentrations lower than $22 \mu \mathrm{mol} \mathrm{L} \mathrm{L}^{-1}$ (sub-oxic conditions) (Helly \& Levin 2004). Notably, the distribution of iGDGTs in sub-oxic waters exhibit an elevated contribution of GDGT-2 and -3, thereby yielding $\mathrm{TEX}_{86}$-derived temperature values that largely offset in situ temperature (Schouten et al. 2012a, 2012b; Xie 2013). Most studies suggest that pelagic Thaumarchaeota are the most likely biological source of iGDGTs in epipelagic and mesopelagic environments, including sub-oxic settings (DeLong et al. 1998; Sinninghe Damsté et al. 2002a, 2002b; Francis et al. 2005; Herndl et al. 2005; Wuchter et al. 2005; Pitcher et al. 2011b; Schouten et al. 2012a). However, the potential contribution of euryarchaeota, as well as the role of environmental variables other than temperature on the relative contribution of different iGDGTs, remains controversial. The distribution of iGDGTs in sub-oxic environments suggests that facultative anaerobic organisms involved in the cycling of $\mathrm{C}$ and $\mathrm{N}$ are potential sources. 
However, few environmental studies have investigated the spatial and temporal variability of iGDGTs and brGDGTs in settings affected by seasonal variations in $\mathrm{O}_{2}$ concentration (e.g. Lengger et al. 2012; Schouten et al. 2012b).

The eastern tropical South Pacific is characterized by a prominent, intermediate-water oxygen minimum zone, maintained by the combined effect of poorly ventilated waters and high microbial respiration of settling organic matter (Pantoja et al. 2004). Intense biological respiration results from the upwelling of nutrient-rich, oxygen depleted equatorial sub-surface water that enhances biological productivity in surface water (Kamykowski \& Zentara 1990; Helly \& Levin 2004). The coastal area off central Chile ( $\left.c a .36^{\circ} \mathrm{S}\right)$, in the southernmost area of intense seasonal upwelling, is one of the most productive areas of the oceans (1-20 $\mathrm{g} \mathrm{C} \mathrm{m}^{-2} \mathrm{~d}^{-1}$; Montero et al. 2007). In this area, fertilization of surface waters occurs seasonally and is driven by an anti-cyclonic atmospheric circulation regime favoring southwesterly winds, leading to the upwelling of equatorial sub-surface water during austral spring-summer (Sobarzo et al. 2007). Consequently, a seasonal oxygen minimum zone develops over the continental shelf off central Chile during spring and summer, expanding from the water-sediment interface up to the photic zone (Ahumada \& Chuecas 1979; Sobarzo et al. 2007). This markedly seasonal oceanographic variability allows the study of spatial and temporal changes in the distribution, composition and abundance of iGDGTs and brGDGTs under varying regimes of nutrient content, productivity and oxygenation.
We investigated the distribution of these two lipid classes in oxic surface and seasonally sub-oxic sub-surface waters and surface sediments during the upwelling and non-upwelling seasons off the coast of Concepción, Chile. The goal was to use these two contrasting conditions to assess if the occurrence of archaea and bacteria responds to oxygenation and water chemistry and reflects on vertical and seasonal patterns of the prokaryotic assemblage, and to evaluate whether the GDGT biomarker signal is imprinted in surface sediments. In order to independently assess Archaeal diversity and abundance, we analyzed PCR-DGGE and 16S rRNA dot blot hybridization in surface and subsurface water samples collected from the study site.

\section{METHODS}

\section{SAMPLING}

The study area (Station $18 ; 36^{\circ} 30.8^{\prime} \mathrm{S} 73^{\circ} 7^{\prime} \mathrm{W}$ ) is ca. 18 nautical miles from the coastline off Concepción, with a depth of $90 \mathrm{~m}$ (Fig. 1). Station 18 is the site of the Oceanographic Time Series maintained by the Center for Oceanographic Research in the eastern South Pacific at University of Concepción (COPAS Center; www.copas. udec.cl/eng/research/serie). The sampling cruises were supported in the framework of the Moore Foundation project "Microbial Initiative in Low Oxygen off Concepción and Oregon (MILOCO; http:// mi_loco.coas.oregonstate.edu) and the COPAS Center.

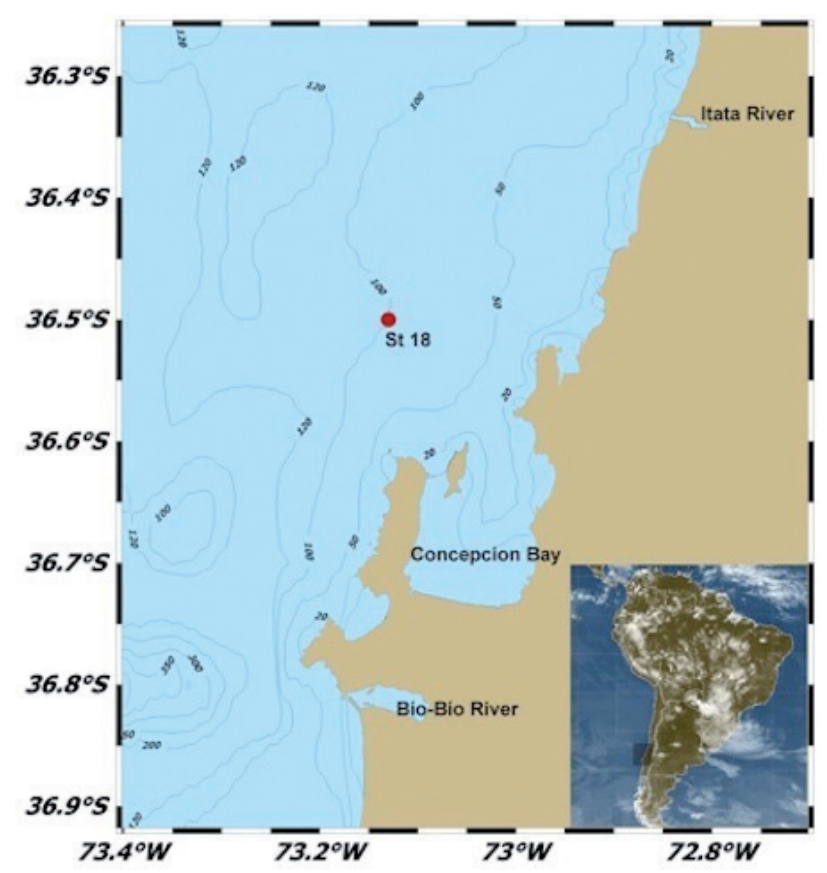

Figure 1. Location of the study site in the upwelling area off Concepción in Central Chile $\left(36^{\circ} \mathrm{S} 73^{\circ} \mathrm{W}\right)$.

Figura 1. Ubicación del sitio de estudio en el area de surgencia de Chile Central $\left(36^{\circ} \mathrm{S} 73^{\circ} \mathrm{W}\right)$. 
Water samples were collected onboard R/V Kay-Kay II in September 2009 (upwelling season) and June 2010 (nonupwelling season), from water masses of contrasting redox conditions. $C a$. $100 \mathrm{~L}$ of seawater were collected at 10 (oxicsurface layer) and $80 \mathrm{~m}$ (seasonal sub-oxic sub-surface layer) depth using a rosette equipped with Niskin bottles. Samples were transferred to darkened carboys and filtered onshore through pre-combusted $\left(450{ }^{\circ} \mathrm{C}, 4 \mathrm{~h}\right)$ glass fiber filters $(0.7 \mu \mathrm{m}$, Millipore) with a peristaltic pump. Ancillary data including temperature, salinity, chlorophyll, and $\mathrm{O}_{2}$ and nutrient concentrations were collected in the whole water column (Fig. 2).

Additionally, a 25 -cm -long sediment core was collected at the same site in February 2009 (summer upwelling season) using a GOMEX BOX corer. In this study, we analyzed the $0-0.25 \mathrm{~cm}$ section.

Upwelling season
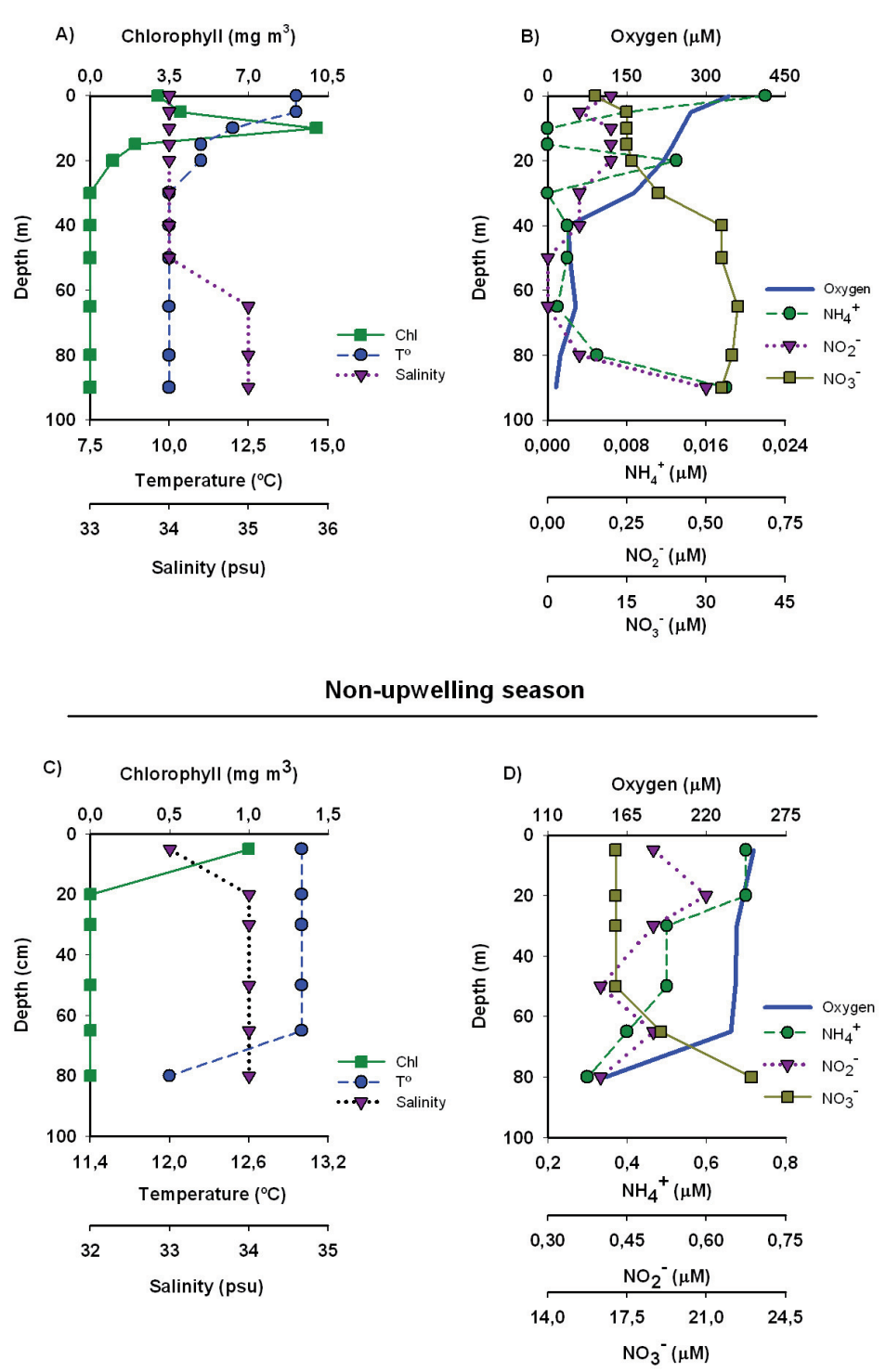

FIGURE 2.Vertical distribution of chlorophyll, temperature, salinity, oxygen, ammonium, nitrite and nitrate during upwelling (September 2009; a-b) and non-upwelling (June 2010; c-d) seasons. Information of the COPAS Center Time Series Oceanographic Station 18 is available at www.copas.udec.cl/eng/research/serie/.

FIgURA 2. Distribución vertical de clorofila, temperatura, salinidad, oxígeno, amonio, nitrito y nitrato durante las estaciones de surgencia (Septiembre 2009; a-b) no-surgencia (Junio 2010; c-d). La información de la Serie de Tiempo de la Estación 18 del Centro COPAS está disponible en: www.copas.udec.cl/esp/investigacion/serie/. 
For PCR-DGGE analyses, we collected water samples at 10 and $80 \mathrm{~m}$ of depth in January (upwelling season; 2006) and June (non-upwelling season; 2006), and in January, February, March, April, June, July, August, September, October, November 2006 for 16S rRNA dot blot hybridization.

Samples $(500 \mathrm{~mL})$ were pre-filtered through $25 \mu \mathrm{m}$ and concentrated by vacuum filtration $(<10 \mathrm{~cm} \mathrm{Hg})$ on cellulose ester filters (pore size $0.22 \mu \mathrm{m}$; GSWP04700; Millipore). Genomic DNA was extracted directly from the thawed filters using the PowerSoil ${ }^{\mathrm{TM}}$ DNA Isolation Kit (MoBio Laboratories, USA). Genomic DNA extracts were stored at $-20^{\circ} \mathrm{C}$ until further PCR-DGGE analyses.

Seven liters of seawater pre-filtered through $25 \mu \mathrm{m}$ and concentrated by vacuum filtration $(<10 \mathrm{~cm} \mathrm{Hg})$ using filters of cellulose ester (pore size $0.22 \mu \mathrm{m}$; GSWP04700, Millipore).

\section{LIPID EXTRACTION AND ANALYSIS}

Filters containing particulate organic matter were sequentially extracted by ultrasonication (3x) with methanol, dichloromethane/methanol (1:1, vol:vol) and dichloromethane. Lipid extracts were concentrated using a rotary evaporator and dried over a small Pasteur pipette filled with combusted glass wool and anhydrous $\mathrm{Na}_{2} \mathrm{SO}_{4}$. Lipids were separated into a non-polar and a polar fractions using a Pasteur pipette filled with activated $\mathrm{Al}_{2} \mathrm{O}_{3}$, after elution with hexane/dichloromethane (9:1, vol:vol) and dichloromethane and methanol(1:1 vol:vol), respectively. For GDGT analysis, an aliquot of the polar fraction was dissolved in hexane/propanol (99:1, vol:vol) and filtered through a $0.45 \mu \mathrm{m}$ PFTE filter. Samples were analyzed using high performance liquid chromatography-mass spectrometry (HPLC-MS), following Hopmans et al. (2000). The HPLC-MS system comprised a 1200 Series HPLC system (Agilent Technologies) equipped with an auto-sampler and a binary pump linked to a Q-TOF 6520 mass spectrometer via an atmospheric pressure chemical ionization interface (Agilent Technologies). Samples were dissolved in $200 \mu \mathrm{l}$ hexane/isopropanol (99:1, vol:vol). The iGDGTs and brGDGTs were separated using a Prevail Cyano column ( $2.1 \times 150 \mathrm{~mm}, 3 \mathrm{~mm}$; Grace, Deerfield, IL, USA) maintained at $35^{\circ} \mathrm{C}$, at a flow rate of $0.25 \mathrm{ml} \mathrm{min}^{-1}$. The elution program was: 5 min 100\% eluent A (hexane/ isopropanol, 99:1, vol:vol) in $20 \mathrm{~min}$, followed by a linear gradient to $100 \%$ eluent B (hexane/isopropanol, 90:10 vol:vol) at $35 \mathrm{~min}$, and then held at $100 \%$ eluent B for 5 min. The column was re-equilibrated with $100 \% \mathrm{~A}$ at a 0.6 $\mathrm{ml} \mathrm{min}{ }^{-1}$ for $5 \mathrm{~min}$ between injections. Semi quantification of core GDGTs was achieved by co-injection of samples with a $\mathrm{C}_{46}$ GDGT standard (Huguet et al. 2010b). Results are given as GDGTs concentration \pm analytical error.
The iGDGTs and brGDGTs (Fig. 3) were identified from their characteristic $[\mathrm{M}+\mathrm{H}]^{+}$ions: GDGT-0 ( $\mathrm{m} / z$ 1302), GDGT-1 ( $\mathrm{m} / \mathrm{z}$ 1300), GDGT-2 ( $\mathrm{m} / \mathrm{z} 1298)$, GDGT-3 $(\mathrm{m} / \mathrm{z}$ 1296), GDGT-4 ( $\mathrm{m} / \mathrm{z}$ 1294), crenarchaeol (Cren) and crenarchaeol regio-isomer (Cren') (m/z 1292), brGDGT-III (m/z 1050); brGDGT-IIIb (m/z 1048); brGDGT-IIIc (m/z 1046); brGDGT-II (m/z 1036), brGDGT-IIc (m/z 1032); brGDGT-I (m/z 1022), brGDGT-IIb (m/z 1034), brGDGT$\mathrm{Ib}(\mathrm{m} / \mathrm{z}$ 1020), brGDGT-Ic (m/z1018).

$\mathrm{TEX}_{86}$ and $\mathrm{TEX}_{86}^{\mathrm{L}}$ indices for suspended particulate matter (SPM) and surface sediments were calculated as described by Schouten et al. (2002) and Kim et al. (2010):

$$
\begin{aligned}
& \mathrm{TEX}_{86}=(\text { GDGT- } 2+\text { GDGT-3 + Cren' }) /(\text { GDGT- } 1+\text { GDGT- } \\
& 2+\text { GDGT-3 + Cren' }) \\
& \mathrm{TEX}_{86}^{\mathrm{L}}=\log [(\text { GDGT-2) } /(\text { GDGT-1 + GDGT- } 2+\text { GDGT- } \\
& 3)]
\end{aligned}
$$

Additionally water column $\mathrm{TEX}_{86}$ values were converted to temperature according to Wuchter et al. (2005):

$\mathrm{TEX}_{86}=0.017 \times \mathrm{T}+0.29$

Sedimentary $\mathrm{TEX}_{86}$ and $\mathrm{TEX}_{86}^{\mathrm{L}}$ values were converted to temperatures \pm (proxy residual error + analytical error) according to Kim et al. (2008):

$\mathrm{SST}=56.2 \times \mathrm{TEX}_{86}-10.8$

and Kim et al. (2010):

$\mathrm{SST}=67.5 \times\left(\mathrm{TEX}_{86}^{\mathrm{L}}\right)+46.9$

In order to assess the overall temporal and spatial variations in iGDGTs we calculated the Ring Index (RI; weighted average number of cyclopentane rings in GDGTs) according to Liu et al. (2011):

Ring Index $=$

$[(\%$ GDGT- 1$)+2(\%$ GDGT- $)+3(\%$ GDGT- $)+$ $5(\%$ Crenarchaeol+Cren') $) / 100$

Assuming that the average number of cyclopentane rings in the GDGT pool increases with growth temperature (Schouten et al. 2002; Wuchter et al. 2004), we could expect a positive relationship between RI and $\mathrm{TEX}_{86}$ values.

The GDGT-2/GDGT-3 ratio was calculated according to Taylor et al. (2013) in order to evaluate the contribution from archaeal community inhabiting deeper water column during both upwelling and non-upwelling contrasting conditions. 


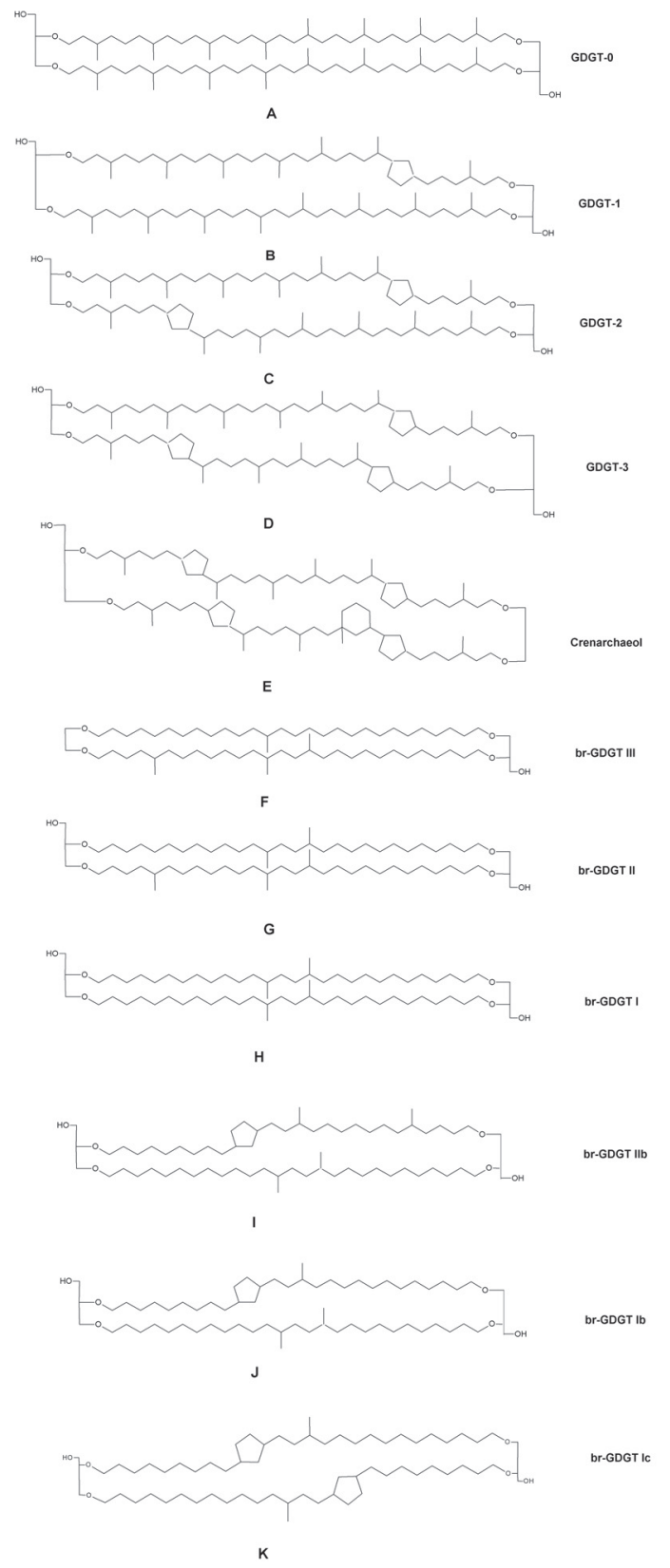

FIGURE 3. Molecular structure of isoprenoid and branched GDGTs mentioned in this study. a: GDGT-0; b, GDGT-1; c, GDGT-2; d, GDGT-3; e, crenarchaeol; f, brGDGT-III; g, brGDGT-II; h, brGDGT-I; i, brGDGT-IIb; j, brGDGT-Ib; k, brGDGT-Ic. Numbers 0-3 represents isoprenoid GDGTs with 0 to 3 pentacyclic rings. Roman numbers III, II, I, IIb, Ib and Ic indicate branched GDGTs with different numbers of methyl groups and pentacyclic rings.

FIGURA 3. Estructura molecular de GDGTs isoprenoides y ramificados mencionados en el presente estudio. a: GDGT-0; b, GDGT-1; c, GDGT-2; d, GDGT-3; e, crenarchaeol; f, brGDGTIII; g, brGDGT-II; h, brGDGT-I; i, brGDGT-IIb; j, brGDGT-Ib; k, brGDGT-Ic. Los números 0-3 representan GDGTs isoprenoides con 0 y 3 anillos penta-cíclicos. Los números romanos III, II, I y Ic indican GDGTs ramificados con diferente número de grupos metilos y anillos penta-cíclicos.
The GDGT-2/crenarchaeol ratio was calculated according to Weijers et al. (2011) in order to evaluate the contribution from Euryarchaeota during both upwelling and nonupwelling conditions.

DNA EXTRACTION FROM SEAWATER AND PCR AMPLIFICATION OF ARCHAEAL 16S RDNAFRAGMENT

PCR $(50 \mu \mathrm{L})$ contained $65 \mathrm{ng}$ of template DNA and $5 \mathrm{x}$ GoTaq flexi buffer (1x; Promega, USA), deoxynucleotide mix $\left(200 \mu \mathrm{mol} \mathrm{L}^{-1}\right), \mathrm{MgCl}_{2}$ solution $\left(3.5 \mathrm{mmol} \mathrm{L}^{-1}\right)$, primers forward and reverse $\left(1 \mu \mathrm{mol} \mathrm{L} \mathrm{L}^{-1}\right.$ each one), and GoTaq polymerase (1.25 U; Promega). Amplicons (580 bp) suitable for subsequent DGGE were obtained with the primer combination 344f-GC (Raskin et al. 1994) and 927r (Kormas et al. 2003) and their respective sequences (5' to 3') are CCGCGCGCGGCGGGCGGGGCGGGGGCCCTACGGGGYGCASCAGGCG and CCCGCCAATTCCTTTAAGTTT. The PCR were performed using a T-personal thermocycler (Biometra, Göttingen, Germany) and the program described elsewhere (Levipan et al. 2012).

\section{DenATURING GRADIENT GEL ELECTROPHORESIS (DGGE)}

Gels were cast using a DCode ${ }^{\mathrm{TM}}$ Universal Mutation Detection System (Bio-Rad Laboratories, USA) as in Levipan et al. (2012). Reliable individual bands were identified using the "Peak Height Threshold" command of the 1 Dscan EX software (v.3.0), which marks the level above which a peak density was considered to be a true band. Gel images were analyzed by assigning numbers to each of the bands (Operational Taxonomic Units $=$ OTUs) on the gel; these were then scored as present (score $=1$ ) or absent (score $=0$ ). The scoring of banding patterns resulted in a binary matrix containing presence/absence data, which were converted into a similarity matrix using the Jaccard coefficient of proximity and the PAST software (version 3.01).

RNA EXTRACTION FROM SEAWATER AND DOT BLOT HYBRIDIZATIONS RNA was extracted from filters as in Summers (1970) with modifications (Levipan et al. 2007a; Quiñones et al. 2009). Extracts were loaded onto nitrocellulose membranes for nucleic acids (Hybond-N; Amersham BioSciences, UK) using a dot blotting apparatus (Bio-Rad, Hercules, CA, USA). Membrane hybridizations analysis was carried out at $44^{\circ} \mathrm{C}$ by using $5^{\prime}$ end digoxigeninlabeled probes (Thermo Biosciences) and the protocol of Raskin et al. (1994). Probes (5' to 3') EUB338 (5'-GCTGCCTCCCGTAGGAGT; Amann et al. 1990) and ARCH915 (5'-GTCCTCCCCCGCCAATTCCT; Stahl \& Amann 1991), allowed to determine the prokaryote 16S rRNA concentration. The EURY498 (5'-CTTGCCCRGCCCCT; Burggraf et al. 1994) and MS1414 (5'-CTCACCCATACCTCACTCGGG; Raskin et al. 1994) probes were used to detect most Euryarchaeota and some methanogens, respectively. 


\section{RESULTS}

OCEANOGRAPHIC CONDITIONS

During the upwelling season (September 2009), surface temperature ranged between 11 and $14^{\circ} \mathrm{C}$, with a thermocline located between 10 and $30 \mathrm{~m}$, whereas bottom temperature was $c a .10^{\circ} \mathrm{C}$ (Fig. 2a). Salinities of $c a .34$ and 35 psu were found above and below $60 \mathrm{~m}$, respectively (Fig. 2a). Chlorophyll concentration peaked at $10 \mathrm{~m}\left(10 \mathrm{mg} \mathrm{m}^{-3}\right.$; Fig. 2a) and then rapidly decreased with depth. $\mathrm{O}_{2}$ concentration varied between 271 and $343 \mu \mathrm{mol} \mathrm{L}^{-1}$ in the top $5 \mathrm{~m}$, with an oxycline between 5 and $40 \mathrm{~m}$ and dropped to $16 \mu \mathrm{mol}$ $\mathrm{L}^{-1}$ (sub-oxic conditions) in bottom water (Fig. 2b). The presence of a shallow oxycline, coupled with high salinity and low $\mathrm{O}_{2}$ concentration through part of the water column suggests the presence of upwelled equatorial sub-surface water during this period (Brandshost 1971; Sobarzo et al. 2007). Under these conditions, $\mathrm{NH}_{4}^{+}$concentration was $<$ $0.02 \mu \mathrm{mol} \mathrm{L}^{-1}$ with maxima at $20 \mathrm{~m}$ and in bottom water (Fig. 2b). $\mathrm{NO}_{2}^{-}$concentration was $<0.5 \mu \mathrm{mol} \mathrm{L}{ }^{-1}$, with minimum values at $50-60 \mathrm{~m}$, and a maximum concentration in bottom water. $\mathrm{NO}_{3}{ }^{-}$concentration up to $35 \mu \mathrm{mol} \mathrm{L}{ }^{-1}$ was detected. $\mathrm{NO}_{3}^{-}$was not fully exhausted in surface water and increased with depth (Fig. 2b).

During the non-upwelling season (June 2010), temperature was homogeneous around $13{ }^{\circ} \mathrm{C}$ at the top $60 \mathrm{~m}$ and dropped to $12{ }^{\circ} \mathrm{C}$ near the bottom (Fig. 2c). Salinity was $<33$ psu at the surface and increased to 34 psu below $20 \mathrm{~m}$ (Fig. 2c). Chlorophyll concentration was highest $\left(1 \mathrm{mg} \mathrm{m}^{-3}\right)$ at the surface, and was not detected below $20 \mathrm{~m}$ (Fig. 2c). $\mathrm{O}_{2}$ concentration was $>237 \mu \mathrm{mol} \mathrm{L}^{-1}$ in the upper $65 \mathrm{~m}$ and dropped to $150 \mu \mathrm{mol} \mathrm{L}{ }^{-1}$ below $80 \mathrm{~m}$ (Fig. 2d). The occurrence of a less saline, warmer, well oxygenated, and less stratified water column compared with the upwelling season indicates the presence of Intermediate Antarctic water (Brandhorst 1971) and a well-mixed water column during this period. $\mathrm{NH}_{4}^{+}$concentration was higher than during the upwelling season and decreased from $0.7 \mu \mathrm{mol}$ $\mathrm{L}^{-1}$ at the surface to $0.3 \mu \mathrm{mol} \mathrm{L}{ }^{-1}$ in bottom water. $\mathrm{NO}_{3}{ }^{-}$varied between 17 and $25 \mu \mathrm{mol} \mathrm{L}^{-1}$ from the surface to bottom water, whereas a general decrease in $\mathrm{NO}_{2}^{-}$concentration with depth was observed (Fig. 2d).

SPATIAL AND TEMPORAL VARIATION OF IGDGTS AND BRGDGTS GDGT-0 and crenarchaeol were the dominant iGDGTs during both seasons and water depths (Fig. 4a, 4b). During the upwelling season, only GDGT-0 (49\%), crenarchaeol $(50 \%)$ and Cren' $(0.7 \%)$ were detected in surface waters, whereas GDGT-0 (39\%), crenarchaeol (52\%) and GDGT1 (5\%), GDGT-2 (4\%), GDGT-3 (0.4\%), and Cren' $(0.7 \%)$ were found in subsurface sub-oxic water (Fig. 4a). During the non-upwelling season, only GDGT-0 (49\%), GDGT-1 $(3 \%)$, crenarchaeol $(48 \%)$ and Cren' $(0.1 \%)$ were detected in surface waters, whereas GDGT-0 (46\%), GDGT-1 (3\%),
GDGT-2 (2\%), GDGT-3 (1\%), crenarchaeol (48\%) and Cren' $(0.3 \%)$ occurred in subsurface water (Fig. $4 b)$. The degree of cyclization of iGDGTs, expressed as the Ring Index, was higher in the subsurface water during upwelling conditions (ca. 3) than during the non-upwelling season (ca. 2) (Table 1). The GDGT-2/GDGT-3 ratio in subsurface water was higher during upwelling ( $c a .9$ ) than non-upwelling ( $c a .4$ ) conditions (Table 1). The GDGT-2/crenarchaeol ratio was higher in sub-surface water during upwelling (0.2; Table 1$)$ compared to non-upwelling (0.04; Table 1$)$. In both seasons, archaeal GDGTs were more abundant in subsurface water $(80 \mathrm{~m})$, whereas bacterial GDGTs were more abundant in surface water $(10 \mathrm{~m}$; Fig. 5a, 5b). During the upwelling season, the concentration of iGDGTs was $0.43 \pm 0.08 \mathrm{ng}$ $\mathrm{L}^{-1}$ in surface water and of $0.91 \pm 0.2 \mathrm{ng} \mathrm{L}^{-1}$ in subsurface water (Fig. 4a). During the non-upwelling season, the concentration of iGDGTs was $2.7 \pm 0.5 \mathrm{ng} \mathrm{L}^{-1}$ in surface water and $36.3 \pm 7.2 \mathrm{ng} \mathrm{L}^{-1}$ in subsurface water (Fig. 4b).

During the upwelling season, only brGDGT-I was found in surface $\left(0.08 \pm 0.02 \mathrm{ng} \mathrm{L}^{-1}\right)$ and sub-surface $(0.07 \pm 0.01 \mathrm{ng}$ $\mathrm{L}^{-1}$ ) waters (Fig. 5a), while during non-upwelling conditions, we detected brGDGT-Ic $\left(0.3 \pm 0.06 \mathrm{ng} \mathrm{L}^{-1}\right)$, brGDGT-I $(0.2$ $\left.\pm 0.04 \mathrm{ng} \mathrm{L}^{-1}\right)$, and brGDGT-II $\left(0.1 \pm 0.02 \mathrm{ng} \mathrm{L}^{-1}\right)$ in surface, and brGDGT-III $\left(0.1 \pm 0.02 \mathrm{ng} \mathrm{L}^{-1}\right)$ in sub-surface waters (Fig. 5b).

Sedimentary iGDGTs were dominated by GDGT-0 (53\%) and crenarchaeol (34\%) followed by GDGT-1 (7\%), GDGT-2 (4\%), GDGT-3 (1\%) and Cren' (2\%) (Fig. 6a), and their total concentration was of $28.4 \pm 5.7 \mu \mathrm{g}$ (g dry wt. $)^{-1}$ (Fig. 6b). The GDGT-2/GDGT-3 ratio in surface sediment resembled that of subsurface water during the non-upwelling season (ca. 4, Table 1).

The distribution of sedimentary brGDGTs was dominated by GDGT-III (46\%), GDGT-I (23\%) and GDGT-II (14\%). Pentacyclic brGDGTs IIb (8\%), Ib (6\%), and Ic (2\%) were minor components (Fig. 6b). Their total concentration was $0.6 \pm 0.1 \mu \mathrm{g}$ (g dry wt. $)^{-1}$.

\section{TEX $_{86}{ }^{-}$-DERIVED TEMPERATURES}

We compared $\mathrm{TEX}_{86}{ }^{-}$and $\mathrm{TEX}_{86}^{\mathrm{L}}$-derived temperatures from particulate matter and surface sediments, with in situ temperature. However, due to the absence of GDGTs -2 and -3 from surface water, temperatures were only calculated for subsurface water. During the upwelling and non-upwelling seasons, TEX $_{86}$ converted to temperature using eq. 3 (12 \pm 2 ${ }^{\circ} \mathrm{C}$ and $14 \pm 3^{\circ} \mathrm{C}$, respectively) were about $2{ }^{\circ} \mathrm{C}$ higher than in situ temperatures (Table 1). In surface sediments, values of $17 \pm 5{ }^{\circ} \mathrm{C}$ and $15 \pm 7{ }^{\circ} \mathrm{C}$; were obtained using $\mathrm{TEX}_{86}$ and $\mathrm{TEX}_{86}{ }^{\mathrm{L}}$ converted to temperatures using equations 4 and 5 , respectively, being 5 and $3{ }^{\circ} \mathrm{C}$ higher than the reported annual mean SST in the study site $\left(12^{\circ} \mathrm{C}\right.$; Table 1$)$. 

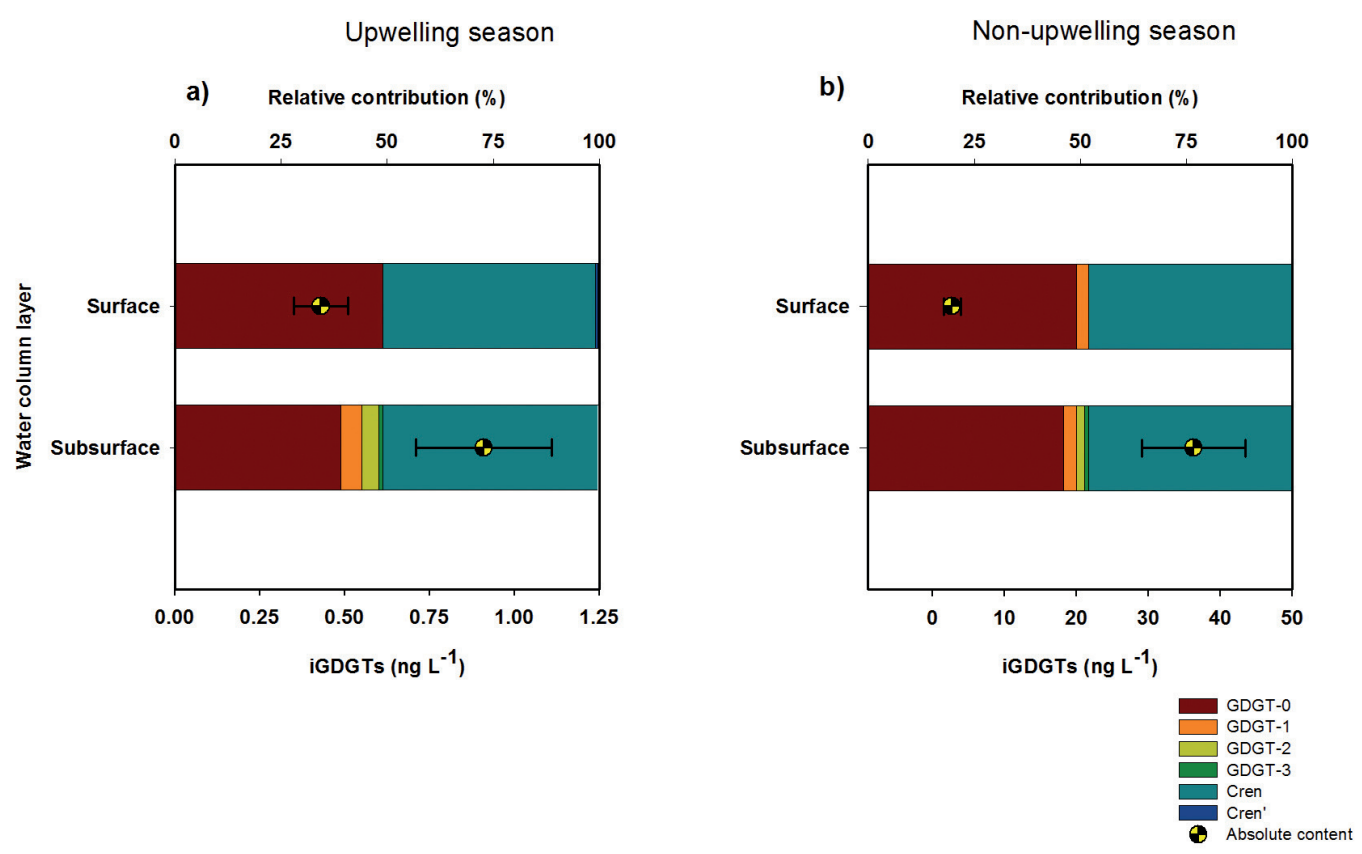

FigURE 4. Relative and absolute concentrations of isoprenoid GDGTs during the (a) upwelling and (b) non-upwelling seasons.

FIgURA 4. Concentraciones relativas y absolutas de GDGTs isoprenoides durante las estaciones de (a) surgencia y (b) no-surgencia.
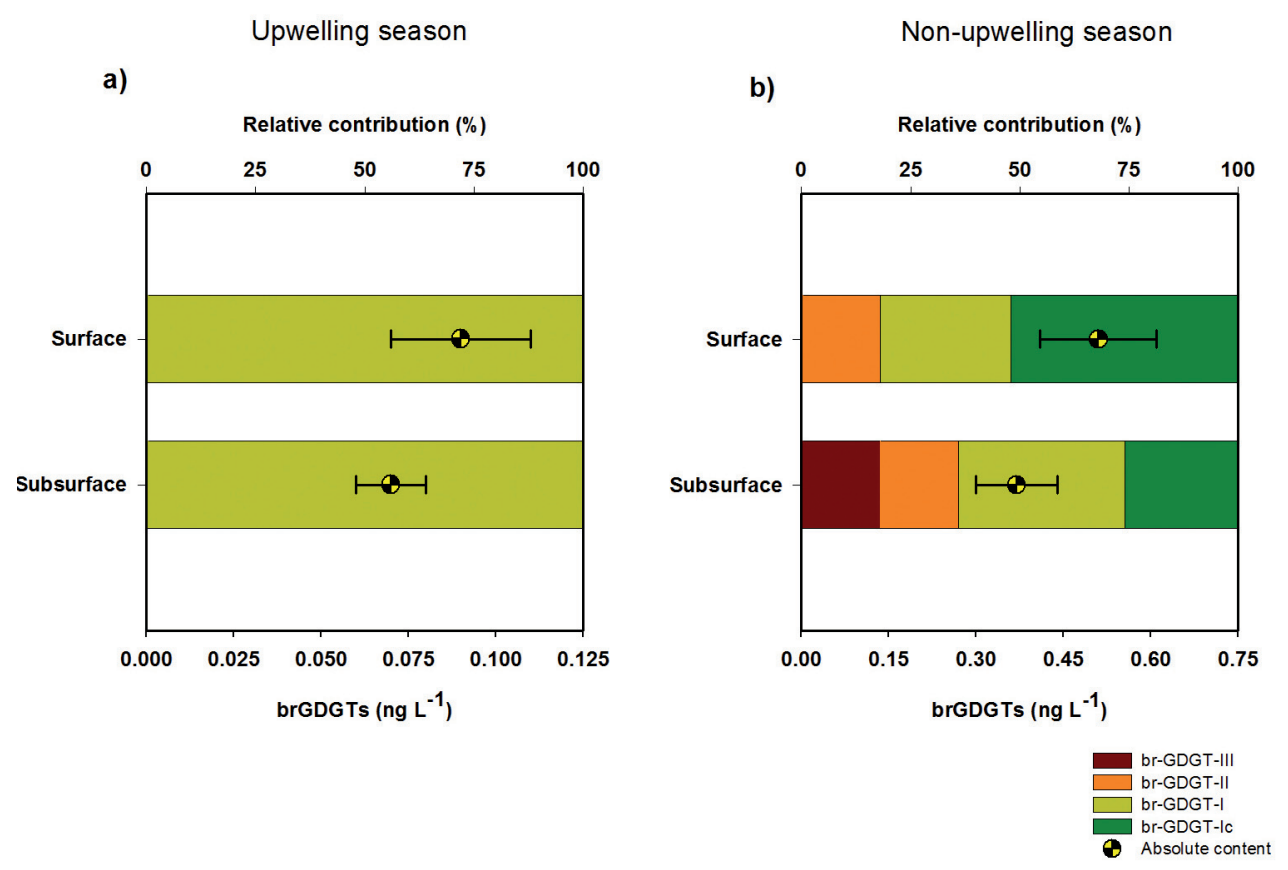

FIGURE 5. Relative and absolute concentrations of branched GDGTs during the (a) upwelling and (b) non-upwelling seasons.

Figura 5. Concentraciones relativas y absolutas de GDGTs ramificados durante las estaciones de (a) surgencia y (b) no-surgencia. 


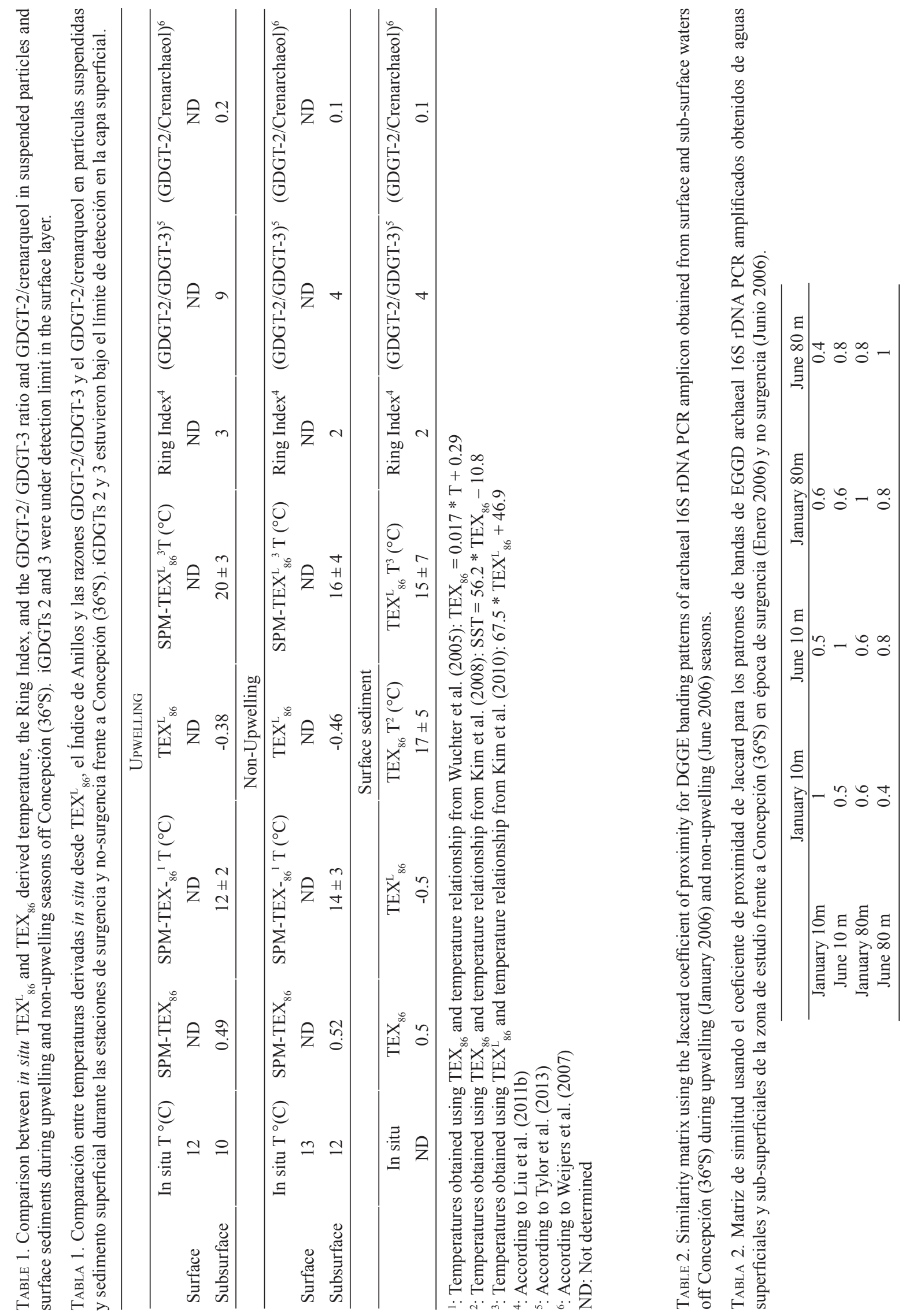


a)

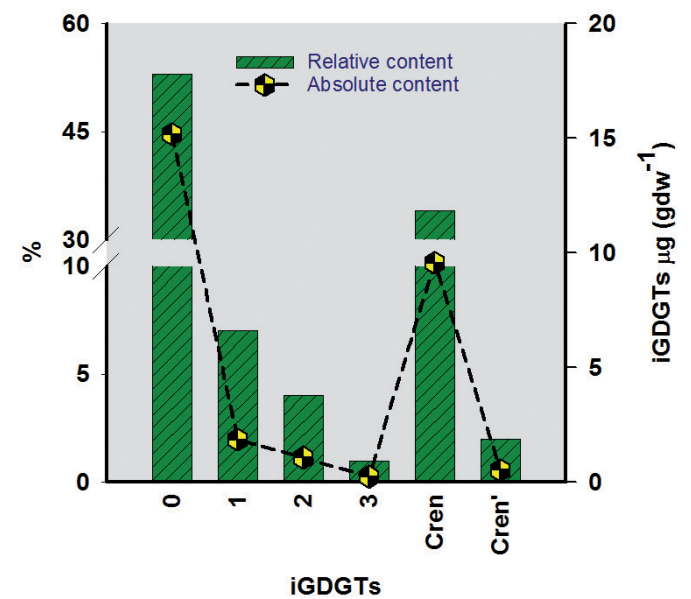

b)

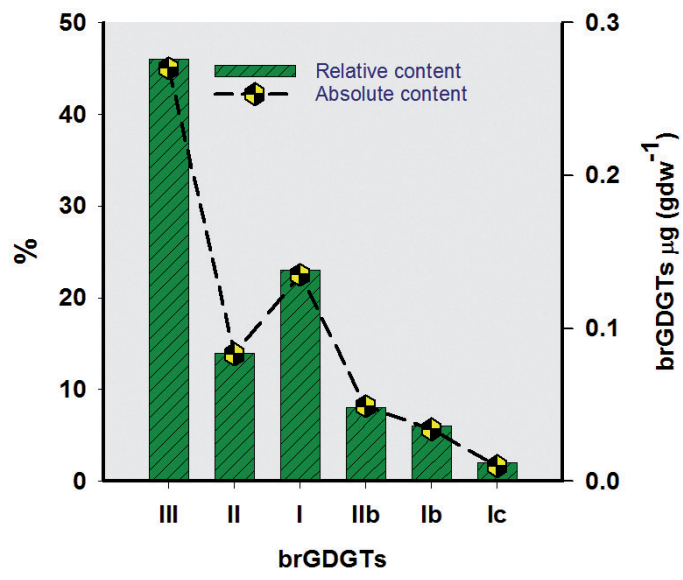

FIGURE 6. Relative contribution and absolute concentration of (a) isoprenoid and (b) branched GDGTs in a top-core sediment sample at Station 18.

Figura 6. Contribución relativa y concentración absoluta de los GDGTs (a) isoprenoides y (b) ramificados en una muestra superficial de un testigo de sedimento en la Estación 18.

VERTICAL AND SEASONAL VARIABILITY IN THE RELATIVE ABUNDANCE OF ARCHAEAL RIBOTYPES IN THE STUDY SITE At the subsurface suboxic water ( $80 \mathrm{~m}$ depth), the relative contribution of Archaea ranged between $\sim 5$ and $38 \%$, and was the highest during the austral summer-spring, specifically in February and September (Fig. 7). The euryarchaeal relative abundance ranged from 0.1 to $5 \%$ (see EURY498 in Fig. 7), and a lower contribution of methanogens was detectable only during the January $(0.9 \%)$ and February (3.9\%) months.

In addition, an interesting secondary peak in the relative abundance of Archaea was observed in the winter season at 10 (July) and $80 \mathrm{~m}$ (June) of depth (Fig. 7).

VERTICAL AND SEASONAL SHIFTS IN THE COMPOSITION OF THE ARCHAEAL COMMUNITY
The DGGE profiles showed inter and intra-seasonal changes in the epipelagic archaeal communities off Concepción. During summer (upwelling), surface water showed 3 main archaeal ribotypes (OTUs), while in the subsurface water we detected 5 dominant archaeal ribotypes (Fig. 7). Both depths share $60 \%$ of the OTUs (Table 2 ).

During winter (non-upwelling) there were 3 dominant archaeal ribotypes in surface water and 4 in subsurface water yielding a higher percent of similitude in both depths (75\%; Fig. 7; Table 2).

A marked inter-seasonal change in the archaeal community composition was more evident in surface than sub-surface water. In surface water, the similitude between summer and winter was $50 \%$, while in sub-surface water the similitude was $80 \%$ (Table 2). 


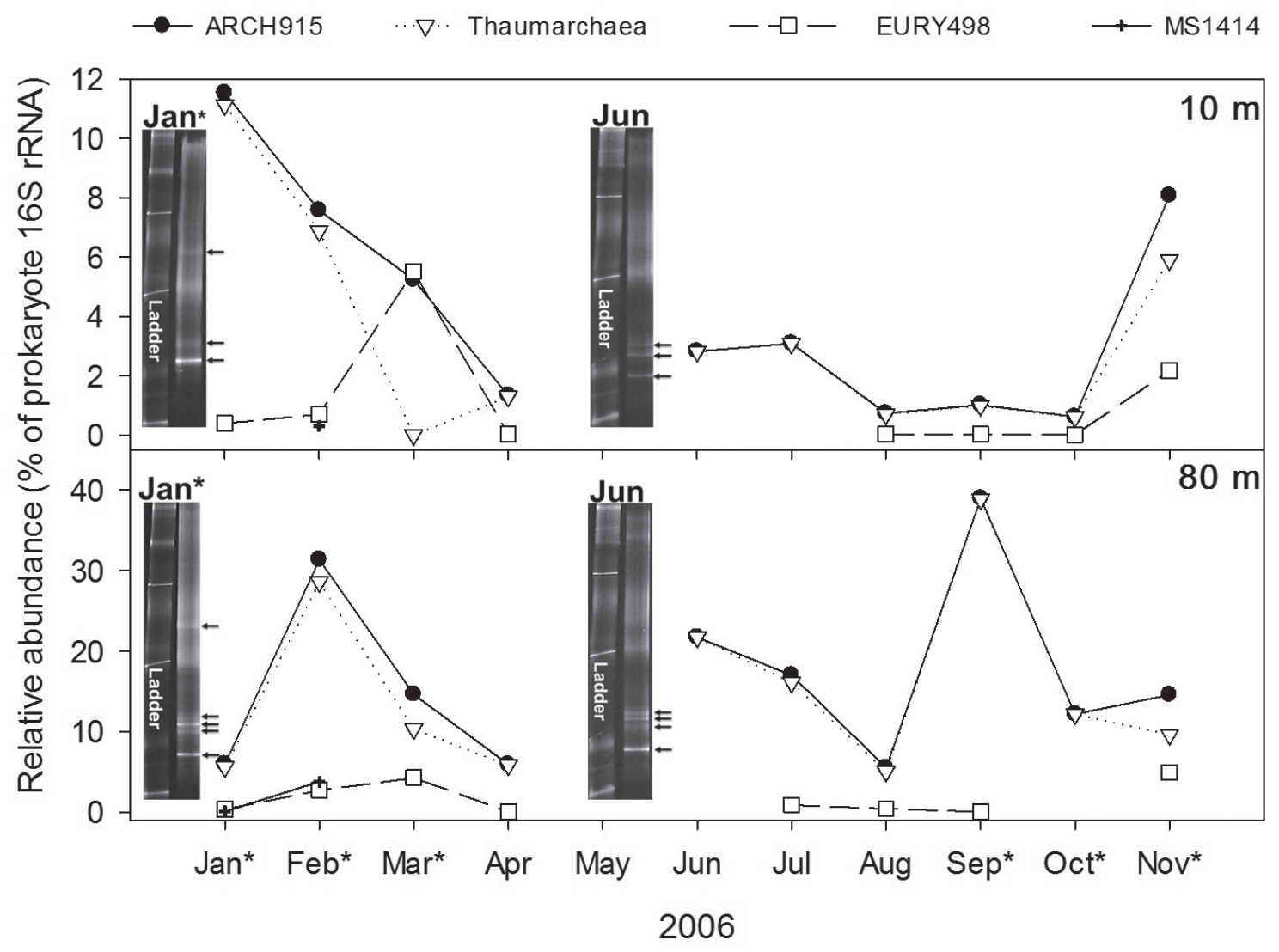

FIGURE 7. Abundance of total archaeal ribotypes (ARCH915, domain-specific probe), most crenarchaeota (CREN499, able to recognize representatives of thaumarchaeota initially classified as 'Marine Group 1 crenarchaeota'), most euryarchaeota (EURY498) and some versatile methanogens (MS1414) at 10 and $80 \mathrm{~m}$ depth in the st.18 as determined by quantitative dot-blot 16S rRNA hybridizations. The abundances are expressed as a percentage of prokaryote rRNA that was determined by adding archaeal rRNA plus (ARCH915) bacterial one (EUB338). Months (2006) marked with asterisks show the upwelling-favorable period in the study area. No samples were available in May. Other gaps correspond to dates when the target groups were below detection limit. A comparative denaturing gradient gel electrophoresis (DGGE) profile analysis of archaeal 16S rDNA gene is shown for January and June (2006) at both depths. Arrows show bands that were reliably selected for similarity analysis by using the 1Dscan EX software.

FiguRA 7. Abundancias totales de lo ribo-tipos arqueanos (prueba del dominio-específico ARCH915), la mayoría de las crenarchaeotas (CREN499, capaz de reconocer representantes de thaumarchaeota, inicialmente clasificados como "Grupo Marino 1 crenarchaeota"), la mayoría de las euryarchaeotas (EUYR498) y algunos metanógenos versátiles (MS1414) a 10 y 80 m de profundidad en la est. 18 determinados mediante hibridaciones cuantitativas de dot-blot $16 \mathrm{~S}$ rARN. Las abundancias son expresadas como el porcentaje del rARN procarionte total, el cual fue determinado por la adición del rARN arqueano (ARCH915) más uno bacteriano (EUB338). Los meses etiquetados con asteriscos muestran el periodo favorable de surgencia en el área de estudio (2006). No hubieron muestras disponibles en Mayo. Los otros espacios vacíos corresponden a las fechas cuando los grupos objetivos estuvieron bajo el límite de detección. Un análisis de perfil comparativo de electroforesis en gel con gradiente de desnaturalización de genes 16S rADN arqueanos son mostrados en Enero y Junio (2006) para ambas profundidades. Las flechas muestran las bandas que fueron seleccionadas confiablemente para el análisis de similitud utilizando el programa 1Dscan EX. 


\section{DISCUSSION}

SPATIAL AND TEMPORAL VARIABILITY OF ARCHAEAL GDGTS IGDGTs concentrations were higher in the deeper subsurface water compared to surface water during upwelling and non-upwelling seasons (Figs. 4 a, b). The iGDGTs depth distribution in our study site showed a similar pattern to those found at the equatorial Pacific, northeast Pacific, Santa Monica Basin (Wuchter et al. 2005), the Arabian Sea (Sinninghe Damsté et al. 2002a), and the Cariaco Basin (Wakeham et al. 2004). The seasonal contrast in the iGDGTs abundance observed off Concepción is also consistent with previous reports. A higher abundance of iGDGTs during winter in the North Sea was reported by Wuchter et al. (2005) and Herfort et al. (2006), suggesting that Thaumarchaeota thrive in winter due to lack of competition with phytoplankton for $\mathrm{NH}_{3}$ (Yamamoto et al. 2012). Similarly, we found the highest abundance of core iGDGTs in suspended particulate matter collected in austral-winter (June 2010, Fig. 4b) when primary production was the lowest (Fig. 2c). Consequently, one could infer that maximum production of iGDGTs off Concepción could correspond to a seasonal bloom of Thaumarchaeota during austral-winter season. This conclusion must be taken with caution, although not completely discarded, since recent evidence has shown that intact iGDGTs are present in the free-living particle size fraction $0.2-0.7 \mu \mathrm{m}$, and core iGDGTs are enriched in suspended particles $(0.7-60 \mu \mathrm{m})$ and aggregates $>60 \mu \mathrm{m}$, implying that archaeal biomass quickly becomes attached to particles once organisms are dead or dying (Ingalls et al. 2012). Since turnover time of archaeal cells in the water column is on the order of days (Jones et al. 1996), free core iGDGTs we measured must have derived from living or recently dead archaea inhabiting the water column during winter.

The observed distribution of iGDGTs resembles what is described for cold areas where the iGDGTs distribution is dominated by iGDGT-0 (Fig. 3a; 4a, b) and crenarchaeol (Fig. 3e; 4a, b) (Wuchter et al. 2005). However, an increase of 1-3 cyclopentane-containing iGDGTs was observed during the upwelling season, contrary to the expected increase cyclization with temperature, concluded from environmental observations (De Rosa et al. 1986; Uda et al. 2001; Macalady et al. 2004; Boyd et al. 2011), and cultures of marine Thaumarchaeota (Wuchter et al. 2004; Schouten et al. 2007) and thermophilic Archaea (Gliozzi et al. 1983; Ward et al. 1985; De Rosa \& Gambacorta 1988; Uda et al. 2001). The addition of pentacyclic rings in the trans-membrane portions of the lipids imply an enhanced membrane packing and reduced fluidity (Benvegnu et al. 2008) resulting in an molecular adaptive advantage to Archaea thriving in warmer and thermophilic environments, which suggest that the temperature is not the only environmental variable controlling the iGDGTs distribution in the study site. Variations in the distribution of iGDGTs in marine environments could also respond to nutrient regime and energy stress, as well as to variation in the relative contribution of Thaumarchaeota and Euryarchaeota (Pearson \& Ingalls 2013). Possible explanations for this observation are discussed below.

We also observed a higher RI and a larger contribution of GDGT-2 during upwelling, when temperature was generally lower, than during the non-upwelling season (Table 1, Fig. $2 \mathrm{a}, 2 \mathrm{~b})$. When water column $\mathrm{TEX}_{86}$-derived temperature increases, RI values decreased, contrary to the expected positive relationship between these two parameters when water temperature is the main factor controlling the composition and distribution of iGDGTs (Table 1). A similar decoupling has been observed in waters associated with gas hydrates where iGDGTs are derived from methanotrophic archaea (Zhang et al. 2011). This evidence suggests that factors other than temperature might control the distribution of iGDGTs in the seasonal upwelling system off Concepción, and consequently $\mathrm{TEX}_{86}$-derived temperature values. This notion is supported by studies indicating that pelagic Thaumarchaeotal communities vary seasonally in response to oceanographic variability including nutrient concentration and $\mathrm{O}_{2}$ content (Massana et al. 1997; Murray et al. 1998a, 1998b; Wutcher et al. 2004; Herfort et al. 2007; Pitcher et al. 2011b; Bale et al. 2013). Since it has been suggested that not all planktonic Thaumarchaeota are strict autotrophs (Ouverney \& Fuhrman 2000; Ingalls et al. 2006; Pearson \& Ingalls 2013), metabolic diversity might also control the number of cyclic moieties due to modification of membrane lipid associated to episodic or chronic energy stress (van de Vossenberg et al. 1998; Mathai et al. 2001; Valentine 2007; Pearson \& Ingalls 2013).

We observed that crenarchaeol increased its relative abundance during the upwelling season, mainly within oxygen-deficient waters, concomitant with the intrusion of nutrient-rich, high salinity and low temperature Equatorial Sub-Surface Waters (Figs. 2a, 4a). Crenarchaeol has been isolated in the non-thermophilic group-I crenarchaeota, a subgroup of archaea occurring in seawater and lakes as well as in soils (Sinninghe Damsté et al. 2002b; Koga \& Morii 2005; Schouten et al. 2007; Weijers et al. 2007). Recently, Lincoln et al. (2014) reported that MG-II Euryarchaeota are a major source of iGDGTs particularly crenarchaeol in shallow and intermediate waters of North Pacific Subtropical Gyre. It has been suggested that the formation of a cyclohexane ring was an adaptive response of crenarchaeota to relatively low temperature environment in which this group evolved (Sinninghe Damsté et al. 2002b). The increased relative abundance of crenarchaeol could indicate a relationship between the decreased water column temperatures observed during upwelling. Alternatively, the coincident increase 
in the relative abundance of crenarchaeol and high ratios GDGT-2/GDGT-3 and GDGT-2/crenarchaeol during upwelling may be the result of an increase of Euryarchaeota in the study site (Table 1; Fig. 7).

Increase in GDGT-2 (Table 1, Fig. 2) has previously been reported in subsurface, sub-oxic water in the Arabian Sea (Schouten et al. 2012), and the eastern tropical North Pacific (Xie 2013), and South Pacific (Sepúlveda et al. 2013). A recent revision of global data sets of suspended organic matter indicates that GDGT-2/GDGT-3 increases with water depth, particularly in water columns affected by $\mathrm{O}_{2}$-deficiency (Taylor et al. 2013), suggesting that GDGT-derived temperature must therefore consider export dynamics and water depth, whereas a growing body of information suggests that $\mathrm{O}_{2}$ concentrations should also be taken into account. However, the exact mechanism behind the increased proportion of GDGT-2 in subsurface waters, especially in sub-oxic areas, remains poorly understood. Although our biomarker data does not allow us to gather further insights into the responsible mechanisms, molecular data support three possible explanations (i) phylogenetically different thaumarchaeotal populations (ii) changes in the relative contribution of Euryarchaeota with depth; (iii) a relationship between archaea and environmental factors other than temperature (e.g. $\mathrm{O}_{2}$, nutrients and $\left.\mathrm{pH}\right)$.

DGGE profiles at the study site support the first mechanism, since we have observed that the dominant archaeal ribotypes of surface water were different from those found in the subsurface water, especially during summer, when subsurface sub-oxic conditions prevailed (Fig. 7, Table 2). In the subsurface water, a higher number of archaeal OTUs were observed during summer and winter, compared with surface water (Fig.7). This segregation agrees previous reports of Levipan et al. (2012), who described two different archaeal communities inhabiting surface and sub-surface coastal waters off Concepción, and the finding of high diversity of ammonia oxidizing archaea in sub-oxic water off Concepción (Molina et al. 2010). However, the role of upwelling in transporting deeper archaea to surface waters can not be neglected as suggested by Santoro et al. (2010) who found gene copies of deep-water archaea in surface waters of the coastal upwelling region off California.

16S rRNA hybridizations data revealed seasonal and vertical changes in the euryarchaeotal and methanogens, with the highest contribution during austral summer, supporting our second explanation (changes in the relative contribution of Euryarchaeota with depth) for the increased proportion of GDGT-2 (Table 1) in sub-surface waters. Similarly, Levipan et al. (2007b) found that abundance and occurrence of methylotrophic methanogenic archaea was the highest and almost exclusively during active upwelling (austral spring-summer) agreeing with values of the index GDGT-2/crenarchaeol reported here (Table 1). The latter is consistent with previous finding in other marine ecosystems such as the North Sea (van der Maarel et al. 1999).

Distribution of archaea and iGDGTs can also be influenced by water chemistry and associated biological production at the study site. The highest abundance of iGDGTs during the non-upwelling season when lower photosynthetic production is verified (Fig. 4b) could be the result of ecological decoupling between phytoplankton and pelagic marine archaea. Wuchter et al. (2005) and Herfort et al. (2007) found high abundance of iGDGTs in winter in the North Sea. The underlying mechanism appears to be competition for nutrients since abundance of intact iGDGTs, and Thaumarchaeota 16 rRNA genes and amoA genes showed a seasonal cycle with a maximum during winter in the North Sea (Pitcher et al. 2011a). In the study area, Molina et al. (2010) found that ammonia-oxidizing archaea community changed according to the oxygen content in waters of eastern South Pacific. Turich et al. (2007) reported variability in iGDGTs composition in the water column at different oceanographic settings suggesting that changes in archaeal ecology, nutrient regimes and oceanographic conditions can potentially iGDGTs composition. Even though, we detect the pattern, our data set does not allow disentangling whether one or more variables control iGDGTs variability at the study site.

\subsection{ECOlOGiCAL SIGNificANCE OF TEMPORAL AND VERTICAL} DISTRIBUTION OF IGDGTS

The distribution of iGDGTs in the water column off Concepción resembles the characteristic signature found in marine planktonic Thaumarchaeota (Sinninghe Damsté et al. 2002a, 2002b; De la Torre et al. 2008; Schouten et al. 2008). Our biomarker data shown a clear seasonal pattern, with enhanced abundance during the non-upwelling season (austral autumn-winter), particularly in subsurface water coinciding with the molecular data that showed a secondary peak in the archaeal abundance during winter (e.g., JuneJuly) (Fig. 6b, Fig.7). In agreement with this result, Levipan et al. (2007a) and Quiñones et al. (2009) reported that marine Archaea comprise a significant fraction of the planktonic prokaryotic community in subsurface sub-oxic waters ( $\mathrm{ca}$. $50 \%$ of total prokaryote community), where Thaumarchaeota was the dominant group. This seasonal pattern in Thaumarchaeota abundance is consistent with other coastal settings (Wuchter 2006; Wuchter et al. 2006; Herfort et al. 2007; Pitcher et al. 2011b). Thaumarchaeota are more prominent during winter following phytoplankton blooms, and are negatively correlated with chlorophyll concentration (Murray et al. 1998b). In the North Sea, Thaumarchaeota were less abundant when large phytoplankton $(>3 \mu \mathrm{m})$ dominated the algal population, even in the presence of 
favorable nutrient concentrations (Herfort et al. 2007). Thus, it has been hypothesized that nutrient concentration, together with phytoplanktonic biomass and community structure, can control the population of marine Thaumarchaeota (Herfort et al. 2007). In the study area, a phytoplankton assemblage dominated by large diatoms $(>3 \mu \mathrm{m})$ along with high chlorophyll concentration is typically found during the upwelling season (Montero et al. 2007). Conversely, during the non-upwelling season chlorophyll concentration is $c a$. one order of magnitude lower than during the upwelling season, whereas $\mathrm{NH}_{4}^{+}$and $\mathrm{NO}_{2}{ }^{-}$were higher (Fig. 2).

In marine sub-oxic waters, the occurrence of $\mathrm{NH}_{4}{ }_{4}$-oxidizing archaea is well correlated with crenarchaeol concentrations (De Long et al. 1998; Schouten et al. 2000). A previous study from the same site (Station 18) indicates that most of the archaeal amoA gen belongs to the uncultured cluster A, when sub-oxic conditions and high $\mathrm{NH}_{4}^{+}$concentration prevail (Molina et al. 2010). $\mathrm{NH}_{4}^{+}$concentrations were in average 42 times higher during the non-upwelling period than during upwelling (Fig. 2b, d), yielding a greater $\left(\mathrm{NH}_{4}^{+}\right.$ $+\mathrm{NO}_{2}^{-}$) to P ratio during winter (13 vs. 10 during upwelling) when higher abundance of iGDGTs (Fig. 4) occurs, suggesting that Thaumarchaeota abundance depends on $\mathrm{NH}_{4}^{+}$availability in the water column of the study site.

The ecological role of Thaumarchaeota in the marine $\mathrm{N}$ cycle has been shown by the co-occurrence of crenarchaeol and $\mathrm{NO}_{2}^{-}$maxima (Massana et al. 1997; Murray et al. 1998a, 1998b; Sinninghe Damsté et al. 2002a) as well as archaeal $\mathrm{NH}_{3}$ oxidation genes (amoA) (Francis et al. 2005; Hallam et al. 2006; Wuchter et al. 2006). Our results support previous molecular data obtained from samples of the same site (Levipan et al. 2007a; Molina et al. 2010) that have detected a role of pelagic $\mathrm{NH}_{3}$ oxidizing Archaea in $\mathrm{N}$ cycling in waters of the eastern South Pacific.

Spatial AND TEMPORAL VARIABILITY OF BACTERIAL GDGTS The highest concentration and diversity of brGDGTs were found during the non-upwelling season in surface and subsurface waters (Fig. 5b), consistent with enhanced terrestrial input from rivers Itata and Bíobio during austral winter, based on their terrestrial biological source (Hopmans et al. 2004; Weijers et al. 2006). However, both the water column vertical distribution as well as the large seasonal differences in diversity (Fig. $5 \mathrm{a}, \mathrm{b}$ ) suggest that in situ production cannot be entirely ruled out. Previous studies have demonstrated in situ production in lakes and fjords based on the differences in the degree of methylation and cyclization in soils and the water column (Peterse $e t a l$. 2009; Tierney \& Russel 2009; Tierney et al. 2010).

Although the effect of diagenesis is not well constrained, their stability under oxic and suboxic conditions in the water column cannot be excluded as a control of brGDGT abundance and distribution. Tierney et al. (2012) found a higher abundance of methylated brGDGTs in a seasonally anoxic and eutrophic suburban lake compared with deeper layers of sediments that were deposited under oxygenated conditions. Similarly, Bechtel et al. (2010) observed that anoxic lakes contained preferentially more methylated over cyclized brGDGTs than oxic lakes. In the seasonal upwelling system off Concepción, the absolute predominance of methylated brGDGTs during upwelling conditions (Fig. 4C) could be reflecting the loss of cyclized brGDGTs as result of the exposure to oxygen during austral winter. Alternatively, it could reflect that the organisms synthesizing brGDGTs are sensitive to variations in water column redox, modifying their brGDGTs lipid composition as response to the environmental redox changes of the study site, or by seasonal changes of bacterial producer brGDGTs community structure with changes in the whole oceanographic conditions of water column off Concepción. These uncertainties remain unconstrained at the moment.

\section{CONCLUSIONS}

A seasonal pattern in the distribution and composition of $\mathrm{i}$ and brGDGTs was found in the upwelling ecosystem off Concepción where an Oxygen Minimum Zone develops during austral summer. This pattern reflects the distribution of archaea -traumarcheota in the area as compared with a year round observation of rDNA and rRNA molecular data. The fractional abundances of iGDGTs showed that Euryarchaeota was most prominent during upwelling conditions. The highest abundance and diversity of iGDGTs occurred in sub-surface water during non-upwelling conditions. During upwelling conditions, a higher relative contribution of GDGT-2 was found in subsurface, sub-oxic water, leading to discrepancies between $\mathrm{TEX}_{86}$-derived and in situ temperatures. Similarly, $\mathrm{TEX}_{86}$ derived temperatures from surface sediments yielded values that exceeded seasonal and year averages in surface and subsurface water. Additionally, the distribution of iGDGTs in surface sediments over the continental shelf off Concepción might be biased by the seasonal input of iGDGTs from Euryarchaeota during the upwelling season as well as by soil archaea during the low productivity season in austral fall-winter. The highest abundance of brGDGTs occurred during non-upwelling conditions (austral fallwinter), particularly in surface water.

\section{ACKNOWLEDGEMENTS}

This research was funded by the Center for Oceanographic Research in the eastern South Pacific (COPAS), the Gordon 
and Betty Moore Foundation, the COPAS Sur-Austral Program (PFB-31), and the MIT International Science and Technology Initiatives (MIT-MISTI-Chile). B. S. acknowledges the Ministry of Education's MECESUP Program UCO-0602, the Department of Atmospheric, Earth and Planetary Sciences at MIT, and the Fulbright Chilean Commission for supporting a research visit to the Massachusetts Institute of Technology. We acknowledge the support provided by the COPAS Oceanographic Time Series off Concepción, the crew of the L/C Kay-Kay II, and the personnel of the Marine Organic Geochemistry Laboratory at UDEC and the Geobiology Group at MIT for laboratory assistance. This manuscript was greatly improved by the constructive comments of the Associate Editor, reviewer Dr. Carme Huguet, and one anonymous reviewer. The HanseWissenschaftskolleg (HWK) in Delmenhorst, Germany, provided support to SP.

\section{BIBLIOGRAPHY}

Ahumada, R. \& Chuecas, L. 1979. Algunas características hidrográficas de la Bahía Concepción (36² $\left.40^{\prime} \mathrm{S}-73^{\circ} 02^{\prime} \mathrm{W}\right)$ y áreas adyacentes, Chile. Gayana Miscelánea (Chile) 8:156.

Amann, R.I., Binder, B.J., Olson, R.J., Chisholm, S.W., Devereux, R. \& STAHL, D.A. 1990. Combination of 16S rRNAtargeted oligonucleotide probes with flow cytometry for analyzing mixed microbial populations. Applied Environmental Microbiology 56:1919-1925.

Bale, N.J., Villanueva, L., Hopmans, E.C., Schouten, S. \& SinNinghe DMasté, J.S. 2013. Different seasonality of pelagic and benthic Thaumarchaeota in the North Sea. Biogeosciences Discussions 10:12593-12624.

Bano, N., Ruffin, S., Ransom, B. \& Hollibaugh J.T. 2004. Phylogenetic composition of Arctic Ocean archaeal assemblages and comparison with antarctic assemblages. Applied Environmental Microbiology 70:781-789.

Belicka L.L. \& Harvey, H.R. 2009. The sequestration of terrestrial organic carbon in Arctic Ocean sediments: a comparison of methods and implications for regional carbon budgets. Geochimica et Cosmochimica Acta 73:6231-6248.

Bechtel, A., Smittenberg, R., Bernasconi, S. \& Schubert, C. 2010. Distribution of branched and isoprenoid tetraether lipids in an oligotrophic and a eutrophic Swiss lake: Insights into sources and GDGT-based proxies. Organic Geochemistry 41:822-832.

Benvegnu,T., Lemiègre, L. \& Cammas-Marion, S. 2008 Archaeal Lipids: Innovative Materials for Biotechnological Applications. European Journal of Organic Geochemistry: 4724-4744.

Blaga, C.I., Reichart, G.J., Heiri, O. \& Sinninghe Damsté, J.S. 2009. Tetraether membrane lipid distributions in watercolumn particulate matter and sediments: a study of 47 European lakes along a north-south transect. Journal of Paleolimnology 41:523-540.

Blumenberg, M., Seifert, R., Reitner, J., Pape, T. \& Michaelis, W. 2004. Membrane lipid patterns typify distinct anaerobic methanotrophic consortia. Proceedings of the National Academy of Sciences USA101:11111-11116.

Boyd, E., Pearson, A., Pi, Y., Li, W.J., Zhang, Y., He, L., Zhang, C.L. \& GeEsEY, G. 2011. Temperature and pH controls on glycerol dibiphytanyl glycerol tetraether lipid composition in the hyperthermophilic crenarchaeon Acidilobus sulfurireducens. Extremophiles 15:59-65.

Brandhorst, W. 1971. Condiciones oceanográficas estivales frente a la costa de Chile. Revista de Biología Marina 3:45-48.

Brochier-Armanet, C., Boussau, B., Gribaldo, S. \& Forterre, P. 2008. Mesophilic Crenarchaeota: proposal for a third archaeal phylum, the Thaumarchaeota. Nature Reviews Microbiology 6:245-252.

Burggraf, S., Mayer, T., Amann, R., Schadhauser, S., Woese, C.R. \& Stetter, K.O. 1994. Identifying Archaea with rRNAtargeted oligonucleotide probes. Applied Environmental Microbiology 60:3112-3119.

De la Torre, J.R., Walker, C.B., Ingalls, A.E., Könneke, M. \& Stahl, D.A. 2008. Cultivation of a thermophilic ammonia oxidizing archaeon synthesizing crenarchaeol. Environmental Microbiology 10:810-818.

DeLong, E.F. 1992. Archaea in coastal marine environments. Proceedings of the National Academy of Sciences USA 89:5685-5689.

DeLong, E.F., Wu, K.Y., Prézelin, B.B. \& Jovine, R.V.M. 1994. High abundance of Archaea in Antarctic marine picoplankton. Nature 371:695-697.

DeLong, E.F., King, L.L., Massana, R., Cittone, H., Murray, A., Schleper, C. \& Wakeham, S.G. 1998. Dibiphytanyl ether lipids in nonthermophilic crenarchaeotes. Applied and Environmental Microbiology 64:1133-1138.

DeLong, E.F. 2003. Oceans of Archaea. American Society for Microbiology News 69 (10):503-511.

De Rosa, M., Gambacorta, A. \& Gliozzi, A. 1986. Structure, biosynthesis, and physicochemical properties of archaebacterial lipids. Microbiology Reviews 50:70-80.

De Rosa, M. 1996. Archaeal lipids: structural features and supramolecular organization. Thin Solid Films 284(285):13-17.

De Rosa, M. \& Gambacorta, A. 1988. The lipids of archaeabacteria. Progress in Lipid Research 27:153-175.

Fietz, S., Huguet, C., Bendle, J., Escala, M., Gallacher, C., Herfort, L., Jamieson, R., Martínez-Garcia, A., McClymont, E.L., Peck, V.L., Prahl, F.G., Rossi, S., Rueda, G., SAnson-Barrera, A. \& Rosell-Melé, A. 2012. Co-variation of crenarchaeol and branched GDGTs in globally-distributed marine and freshwater sedimentary archives. Global and Planetary Change 92(93):275-285.

Francis, C.A., Roberts, K.J., Beman, M., Santoro, A.E. \& OAKLEY, B.B. 2005. Ubiquity and diversity of ammoniaoxidizing archaea in water columns and sediments of the ocean. Proceedings of the National Academy of Sciences USA 102:14683-14688.

Fuhrman, J.A., McCallum, K. \& Davis, A.A. 1992. Novel major archaebacterial group from marine plankton.Nature 356:148-149.

Gliozzi, A., Paoli, G., De Rosa, M. \& Gambacorta, A. 1983. Effect of isoprenoid cyclization on the transition temperature of lipids in thermophilic archaeabacteria.Biochimica et Biophysica Acta 735:234-242.

Hallam, S.J., Mincer, T.J., Schleper, C., Preston, C.M., Roberts, 
K., Richardson, P.M. \& DeLong, E.F. 2006. Pathways of carbon assimilation and ammonia oxidation suggested by environmental genomic analyses of marine Crenarchaeota. Plos Biology 4:520-536.

Helly, J.J. \& Levin, L.A. 2004. Global distribution of naturally occurring marine hypoxia on continental margins. DeepSea Research I 51:1159-1168.

Herndl, G.J., Reinthaler, T., Teira, E., van Aken, H., Pernthaler, C.V.A. \& Pernthaler, J. 2005. Contribution of Archaea to total prokaryotic production in the deep Atlantic Ocean. Applied and Environmental Microbiology 71:5.

Herfort, L., Schouten, S., Boon, J.P., Woltering, M., BaAs, M., Weijers, J.W.H. \& Sinninghe Damsté, J.S. 2006. Characterization of transport and deposition of terrestrial organic matter in the southern North Sea using the BIT index. Limnology and Oceanography 51:2196-2205.

Herfort, L., Schouten, S., Abbas, B., Veldhuis, M.J.W., Coolen, M.J.L., Wuchter, C., Boon, J.P., Hernd, G.J. \& Sinninghe Damsté, J.S. 2007. Variations in spatial and temporal distribution of Archaea in the North Sea in relation to environmental variables. FEMS Microbiology and Ecology 62:242-267.

Hoefs, M.J.L., Schouten, S., King, L., Wakeham, G., De Leewv, J.W. \& Sinninghe Damsté, J.S. 1997. Ether lipids of planktonic archaea in the marine water column. Applied Environmental Microbiology 63:3090-3095.

Hopmans, E.C., Schouten, S., Pancost, R.D., van der Meer, M.T.J. \& Sinninghe Damsté, J.S. 2000. Analysis of intact tetraether lipids in archaeal cell material and sediments by high performance liquid chromatography/atmospheric pressure chemical ionization mass spectrometry. Rapid Communication in Mass Spectrometry 14:585-589.

Hopmans, E.C., Weijers, J.W.H., Schefuss, E., Herfort, L. Sinninghe Damsté, J.S. \& Schouten, S. 2004. A novel proxy for terrestrial organic matter in sediments based on branched and isoprenoid tetraether lipids. Earth and Planetary Sciences Letters 224:107-116.

Huguet, C., Schimmelmann, A., Thunell, R., Lourens, L.J., Damste, J.S.S. \& Schouten, S. 2007. A study of the TEX paleothermometer in the water column and sediments of the Santa Barbara Basin, California. Paleoceanography 22:PA3203, doi:10.1029/2006PA001310.

Huguet, A., Fosse, C., Laggoun-Defarge, F., Toussaint, M.L. \& DerenNe, S. 2010a. Occurrence and distribution of glycerol dialkyl glycerol tetraethers in a French peat bog. Organic Geochemistry 41:559-572.

Huguet, C., Martens-Habbena, W., Urakawa, H., Stahl, D, A. \& IngALls, A.E. 2010b. Comparison of extraction methods for quantitative analysis of core and intact polar glycerol dialkyl glycerol tetraethers (GDGTs) in environmental samples. Limnology and Oceanography Methods 8:127145.

Ingalls, A.E., Shah, S.R., Hansman, R.L., Aluwihare, L.I., Santos, G.M., Druffel, E.R.M. \& Pearson, A. 2006. Quantifying archaeal community autotrophy in the mesopelagic ocean using natural radiocarbon. Proceedings of the National

Academy of Sciences USA 103:6442-6447.

Ingalls, A.E., Huguet, C. \& Truxal, L.T. 2012. Distribution of intact and core membrane lipids of archaeal glycerol dialkyl glycerol tetraethers among size-fractionated particulate organic matter in Hood Canal, Puget Sound.
Applied Environmental Microbiology 78:1480-1490.

Jones, D.R., Karl, D.M. \& Laws, E.A. 1996. Growth rates and production of heterotrophic bacteria and phytoplankton in the North Pacific subtropical gyre. Deep-Sea Research I 43(10):1567-1580.

Kamykowski, D. \& Zentara, S. 1990. Hypoxia in the world ocean as recorded in the historical data set. Deep-Sea Research 37:1861-1874.

Karner, M., DeLong, E.F. \& Karl, D.M. 2001. Archaeal dominance in the mesopelagic zone of the Pacific Ocean. Nature 409:507-510.

KaTES, M. 1992. Archaebacterial lipids: structure, biosynthesis and function. Biochemical Society Symposium 58:51-72.

Kim, J.H., Schouten, S., Hopmans, E.C., Donner, B. \& Sinninghe DAmsté, J.S. 2008. Global core-top calibration of the $\mathrm{TEX}_{86}$ paleothermometer in the ocean. Geochimica et Cosmochimica Acta 72:1154-1173.

Kim, J.H., Buscail, R., Bourrin, F., Palanques, A., Sinninghe Damsté. J.S., Bonnin, J. \& Schouten, S. 2009. Transport and depositional process of soil organic matter during wet and dry storms on the Têt inner shelf (NW Mediterranean). Palaeogeography, Palaeoclimatolgy, Palaeoecology 273:228-238.

Kim, J.H., van der Meer, J., Schouten, S., Helmke, P., Willmott, V., Sangiorgi, F., Koç, N., Hopmans, E.C. \& Sinninghe DAmSTÉ, J.S. 2010. New indices and calibrations derived from distribution of crenarchaeal isoprenoidal tetraether lipids. Implications for past sea surface temperature. Geochimica et Cosmochimica Acta 74:4639-4654.

KogA, Y. \& MoriI, H. 2005. Recent advances in structural research on ether lipids from archaea including comparative and physiological aspects. Bioscience, Biotechnology and Biochemistry 69:2019-34.

Kormas, A.K., Smith, D.C., Edgcomb, V. \& Teske, A. 2003. Molecular analysis of deep subsurface microbial communities in Nankai Through sediments (ODP Leg 190, Site 1176). FEMS Microbiology Ecology 45:115-125.

King, L.L., Pease, T.K. \& Wakeham, S.G. 1998. Archaea in Black Sea water column particulate matter and sediments evidence from ether lipid derivates. Organic Geochemistry 28:667-688.

Kuypers, M.M.M., Blokker, P., Erbacher, J., Kinkel, H., Pancost, R.D., Schouten, S. \& Sinninghe Damsté, J.S. 2001. Massive expansion of marine Archaea during midCretaceous oceanic anoxic events. Science 293:92-94.

Langworthy, T.A., Smith, P.F. \& Mayberry, W.R. 1972. Lipids of thermoplasma acidophilum. Journal of Bacteriology 112:1193-1200

Langworthy, T.A., Holzer, G., Zeikus, J.G. \& Tornabene, T.G. 1983. Iso-and anteiso branched glycerol diethers of the thermophilic anaerobe Thermodesulfobacterium commune. Systematic and Applied Microbiology 4:1-17.

Lengger, S.K., Hopmans, E.C., Reichart, G.J., Nierop, K.G.C., Sinninghe Damsté, J.S. \& Schouten, S. 2012. Intact polar and core glycerol dibiphytanyl glycerol tetraether lipids in the Arabian Sea oxygen minimum zone. Part II: Selective preservation and degradation in sediments and consequences for the $\mathrm{TEX}_{86}$. Geochimica et Cosmochimica Acta 98:244-258.

Levipan, H.A., Quiñones, R.A. \& Urrutia, H. 2007a. A time series of prokaryote secondary production in the oxygen 
minimum zone of the Humboldt current system, off central Chile. Progress in Oceanography 75:531-549.

Levipan, H.A., QuiÑones, R.A., Johansson, H.E. \& Urrutia, H. 2007b. Methylotrophic methanogens in the water column of an upwelling zone with a strong oxygen gradient off Central Chile. Microbes and Environment 22:268-278.

LeVIPAn, H.A., Alarcón, W.O. \& SAldías, G.S. 2012. Fingerprinting analysis of the prokaryote community along a marinefreshwater transect in central-southern Chile. Annals of Microbiology 62:1121-1140.

Lincoln, S.A., Brenner, W., Eppley, J.M., Church, M.J., Summons, R.E. \& DeLong, E.F. 2014. Planktonic Euryarchaeota are significant source of archaeal tetraether lipids in the ocean. Proccedings of the National Academy of Sciences, USA 111(27):9858-9863.

LiU, X., Lipp, J.S. \& HinRichs, K.U. 2011. Distribution of intact and core GDGTs in marine sediments. Organic Geochemistry 42:368-375.

Liu, X., Summons, R.E. \& Hinrichs, K.U. 2012. Extending the known range of glycerol ether lipids in the environment: structural assignments based on MS/MS fragmentation patterns. Rapid Communications in Mass Spectrometry 26:2295-2302.

Lopez-Garcia, P., Moreira, D., Lopez-Lopez, A. \& RodriguezVALERA, F. 2001. A novel haloarchaeal-related lineage is widely distributed in deep oceanic regions. Environmental Microbiology 3:72-78.

Macalady, J.L., Vestling, M.M., Baumler, D., Boekelheide, N., Kaspar, C.W. \& BANFIELD, J.F. 2004. Tetraether-linked membrane monolayers in Ferroplasma spp.: a key to survival in acid. Extremophiles 8:411-419.

Massana, R., Murray, A.E., Preston, C.M. \& DeLong, E.F. 1997. Vertical distribution and phylogenetic characterization of marine planktonic Archaea in the Santa Barbara Channel. Applied and Environmental Microbiology 63:50-56.

Mathai, J.C., Sprott, G.D. \& Zeidel, M.L. 2001. Molecular mechanisms of water and solute transport across archaebacterial lipid membranes. Journal of Biological Chemistry. 276:27266-27271.

Molina, V., Belmar, L. \& Ulloa, O. 2010. High diversity of ammonia-oxidizing archaea in permanent and seasonal oxygen-deficient waters of the eastern South Pacific. Environmental Microbiology 12:2459-2465.

Montero, P., Daneri, G., Cuevas, L.A., GonzÁlez, H.E., Jacob, B., LizÁrraga, L. \& Menschel, E. 2007. Productivity cycles in the coastal upwelling area off Concepción: The importance of diatoms and bacterioplankton in the organic carbon flux. Progress in Oceanography 75:518-530.

Moreira, D., Rodriguez-Valera, F. \& Lopez-Garcia, P. 2004. Analysis of a genome fragment of a deep-sea uncultivated Group II euryarchaeote containing 16S rDNA, a spectinomycin-like operon and several energy metabolism genes. Environmental Microbiology 6:959-69.

Murray, A.E., Preston, C.M., Massana, R., Taylor, L.T., Blakis, A., Wu, K. \& DeLong, E.F. 1998a. Seasonal and spatial variability of bacterial and archaeal assemblages in the coastal waters near Anvers Island, Antarctica. Applied Environmental Microbiology 64:2585-2595.

Murray, A.E., Blakis, A., Massana, R., Strawzewski, S., Passow, U., Alldredge, A. \& DeLong, E.F. 1998b. A time series assessment of planktonic archaeal variability in the Santa
Barbara Channel. Aquatic Microbial Ecology 20:129-145. Murray, A.E., Blakis, A., Massana, R. , Strawzewiski, S. , Passow, U., Alldredge, A. \& Delong, E.F. 1999. A time series assessment of planktonic archaeal variability in the Santa Barbara Channel. Aquatic Microbial Ecology 20:129-145.

Nishihara, M., Morri, H. \& Koga, Y. 1987. Structure determination of a quartet of novel tetraether lipids from Methanobacterium thermoautotrophicum. Journal of Biochemistry 101:1007-1015.

Ouverney, C.C. \& Fuhrman, J.A. 2000. Marine planktonic Archaea take up amino acids. Applied and Environmental Microbiology 66:4829-4833.

Pantoja, S., Sepúlveda, J. \& GonzÁlez, H.E. 2004. Decomposition of sinking proteinaceous material during fall in the oxygen minimum zone off northern Chile. Deep-Sea Research I 51:55-70.

Pearson, A. \& Ingalls, A.E. 2013. Assessing the use of Archaeal lipids as marine environmental proxies. Annual Review of Earth and Planetary Sciences 41:359-384.

Pernthaler, A., Preston, C.M., Pernthale, J., Delong, E.F. \& Amann, R. 2002. Comparison of fluorescence labeled oligonucleotide and polynucleotide probes for the detection of pelagic marine Bacteria and Archaea. Applied Environmental Microbiology 68:661-667.

Peterse, F., Kim, J.H., Schouten, S., Klitgaard-Kristensen, D., Koç, N. \& Sinninghe Damsté, J.S. 2009. Constraints on the application of the MBT/CBT palaeothermometer at high latitude environments (Svalbard, Norway). Organic Geochemistry 40:692-699.

Pitcher, A., Rychlic, N., Hopmans, E.C., Spieck, E., Rijpstra, W.I.C., Ossebanr, J., Schouten, S., Wagner, M. \& Sinninghe Damsté, J.S. 2010. Crenarchaeol dominates the membrane lipids of Candidatus Nitrososphaera gargensis, a thermophilic Group I.1b Archaeon. ISME Journal 4:542552.

Pitcher, A., Wuchter, C., Siedenberg, K., Schouten, S. \& SinNinghe Damsté, J.S. 2011a. Crenarchaeol tracks winter blooms of ammonia-oxidizing Thaumarchaeotal in the coastal North Sea. Limnology and Oceanography 56:2308-2318.

Pitcher, A., Hopmans, E.C., Mosier, A.C., Park, S.J., Rhee, S.K., Francis, C.A., Schouten, S. \& Sinninghe Damsté, J.S. 2011b. Core and intact polar glycerol dibiphytanyl glycerol tetraether lipids of ammonia-oxidizing Archaea enriched from marine and estuarine sediments. Applied and Environmental Microbiology 77:3468-3477.

Powers, L., Werne, J.P., Vanderwoude, A.J., Damste, J.S.S., Hopmans, E.C. \& Schouten, S. 2010. Applicability and calibration of the $\mathrm{TEX}_{86}$ paleothermometer in lakes. Organic Geochemistry 41:404-413.

Quiñones, R.A., Levipan, H.A. \& Urrutia, H. 2009. Spatial and temporal variability of planktonic archaeal abundance in the Humboldt Current System off Chile. Deep-Sea Research II 56:1073-1082.

Raskin, L., Stromley, J.M., Rittmann, B.E. \& Sthal, B.E. 1994. Group-specific 16S rRNA hybridization probes to describe natural communities of methanogens. Applied Environmental Microbiology 60:1232-1240.

Santoro, A.E., Casciotti, K.L. \& Francis, C.A. 2010. Activity, abundance and diversity of nitrifying archaea and 
bacteria in the central California Current. Environmental Microbiology 12:1989-2006.

Schleper, C., Puehler, G., Holz, I., Gambacorta, A., Janekovic, D., Santarius, U., Klenk, H.P. \& Zillig, W. 1995. "Picrophilus gen. nov., fam. nov.: a novel aerobic heterotrophic, thermoacidophilic genus and family comprising archaea capable of growth around $\mathrm{pH} 0$ ". Journal of Bacteriology 177(24):7050-7059.

Schouten, S., Hopmans, E.C., Pancost, R.D. \& Sinninghe DAmsté, J.S. 2000. Widespread occurrence of structurally diverse tetraether membrane lipids: Evidence for the ubiquitous presence of low-temperature relatives of hyperthermophiles. Proceedings of the National Academy of Sciences 97:14421-14426.

Schouten, S., Hopmans, E.C., Schefuss, E. \& Sinninghe Damsté, J.S. 2002. Distributional variations in marine crenarchaeotal membrane lipids: a new tool for reconstructing ancient sea water temperatures? Earth and Planetary Science Letters 204:265-274.

Schouten, S., Van Der Meer, M.T.J., Hopmans, E.C., Rijpstra, W.I.C., Reysenbach, A.L. \& Ward, D.M. 2007. Archaeal and bacterial glycerol dialkyl glycerol tetraether lipids in hot springs of Yellowstone National Park. Applied Environmental Microbiology 73:6181-6191.

Schouten, S., Hopmans, E.C., BaAs, M., Boumann, H., Standfest, S., Könneke, M., Stahl, D.A. \& Sinninghe Damsté, J.S. 2008. Intact membrane lipids of CandidatusNitrosopumilus maritimus, a cultivated representative of the cosmopolitan Mesophilic Group I Crenarchaeota. Applied and Environmental Microbiology 74:2433-2440.

Schouten, S., Irene, W., Rijpstra, C., Durisch-Kaiser, E.,Schubert, C.J. \& Sinninghe Damsté, J.S. 2012a. Distribution of glycerol dialkyl glycerol tetraether lipids in the water column of Lake Tanganyika. Organic Geochemistry 53:34-37.

Schouten, S., Pitcher, A., Hopmans, E.C., Villanueva, L., van Bleisswijk, J. \& Sinninghe Damsté, J.S. 2012b. Intact polar and core glycerol dibiphytanyl glycerol tetraether lipids in the Arabian Sea oxygen minimum zone: I. Selective preservation and degradation in the water column and its consequences for the TEX86. Geochimica et Cosmochimica Acta 98:228-243.

Schouten, S., Hopmans, E.C. \& Sinninghe Damsté, J.S. 2013. The Organic geochemistry of glycerol dialkyl glycerol tetraether lipids. Organic Geochemistry 54:19-61.

Sepúlveda, J., Schubotz, F., Matys, E., Pantoja, S.,Lange, C. \& Summons, R.E. 2013. Vertical and spatial distribution of intact and core archaeal lipids in response to oxygenation gradients. 26th International Meeting on Organic Geochemistry, book of abstracts 1:151-152.

Shimada, H., Nemoto, N., Shida, Y., Oshima, T. \& Yamagishi, A. 2002. Complete polar lipid composition of thermoplasma acidophilum HO-62 determined by High-Performance Liquid Chromatography with Evaporative Light-Scattering Detection. Journal of Bacteriology 184:556-563.

Sinninghe Damsté, J.S., Hopmans, E.C., Pancost, R.D., Schouten, S. \& Geenevasen, J.A.J. 2000. Newly discovered non-isoprenoid dialkyl diglycerol tetraether lipids in sediments. Journal of the Chemical Society, Chemical Communications 23:1683-1684.

Sinninghe Damsté, J.S., Rijpstra, W.I.C., Hopmans, E.C., Prahl,
F.G., Wakeham, S.G. \& Schouten, S. 2002a. Distribution of membrane lipids of planktonic Crenarchaeota in the Arabian Sea. Applied and Environmental Microbiology 68:2997-3002.

Sinninghe Damsté, J.S., Schouten, S., Hopmans, E.C., van Duin, A.C.T. \& Geenevasen, J.A.J. 2002b. Crenarchaeol: the characteristic core glycerol dibiphytanyl glycerol tetraether membrane lipid of cosmopolitan pelagic crenarchaeota. The Journal of Lipid Research 43:1641-1651.

Sinninghe Damste, J.S., Rijpstra, W.I.C., Hopmans, E.C., Weijers, J.W.H., Foesel, B.U., Overmann, J. \& Dedysh, S.N. 2011. 13,16-Dimethyl octacosanedioic acid (iso-diabolic acid), a common membrane-spanning lipid of Acidobacteria subdivisions 1 and 3. Applied Environmental Microbiology 77:4147-4154.

Sinninghe Damsté, J.S., Rijpstra, W.I.C., Hopmans, E.C., Jung, M.Y., Kim, J.G., Rhee, S.K., Stieglmeier, M. \& SchlePer, C. 2012. Intact Polar and Core Glycerol Dibiphytanyl Glycerol Tetraether Lipids of Group I.1a and I.1b Thaumarchaeota in Soil. Applied Environmental Microbiology doi:10.1128/AEM.01681-12.

Sobarzo, M., Bravo, L., Donoso, D., Garcés-Vargas, J. \& SchneIDER, W. 2007. Coastal upwelling and seasonal cycles that influence the water column over the continental shelf off central Chile. Progress in Oceanography 75:363-382.

Stahl, D.A. \& Amann, R. 1991. Development and application of nucleic acid probes. In: Nucleic Acid Techniques in Bacterial Systematics (Eds. E. Stackebrandt \& M. Goodfellow), pp. 205-248. John Wiley and Sons Ltd., Chichester, UK.

Summers, W.C. 1970. A simple method for extraction of RNA from E. coli utilizing diethylpyrocarbonate. Analytical Biochemistry 33:459-463.

Swain, M., Brisson, J.R., Sprott, G.D., Cooper, F.P. \& Patel, G.B. 1997. Identification of beta-L-gulose as the sugar moiety of the main polar lipid Thermoplasma acidophilum. Biochimica et Biophysica Acta Lipids and Lipid Metabolism 1345:56-64.

Taylor, K.W.R., Huber, M., Hollis, C.J., Hernandez-Sanchez, M.T. \& Pancost, R.D. 2013. Re-evaluating modern and Paleogene GDGT distributions: Implications for SST reconstructions. Global and Planetary Change doi: 10.1016/j.gloplacha.2013.06.011.

Tierney, J.E. \& Russell, J.M. 2009. Distributions of branched GDGTs in a tropical lake system: Implications for lacustrine application of the MBT/CBT paleoproxy. Organic Geochemistry 40:1032-1036.

Tierney, J.E., Russell, J.M., Eggermont, E., Hopmans, C., Verschuren, D. \& Sinninghe Damsté, J.S. 2010. Environmental controls on branched tetraether lipid distributions in tropical East African lake sediments. Geochimica et Cosmochimica Acta 74:4902-4918.

Tierney, J.E., Schouten, S., Pitcher, A., Hopmans, E. \& Sinninghe DAmsté, J.S. 2012. Core and intact polar glycerol dialkyl glycerol tetraethers (GDGTs) in Sand Pond Warwick, Rhode island (USA): Insights into the origin of lacustrine GDGTs. Geochimica et Cosmochimica Acta 77:561-581.

Turich, C., Freeman, K.H., Bruns, M.A., Conte, M., Jones, A.D. \& Wakeham, S.G. 2007. Lipids of marine Archaea: Patterns and provenance in the water-column and sediments. Geochimica et Cosmochimica Acta 71:3272-3291. 
Uda, I., Sugai, A., Iтон, Y.H. \& Iтон, T. 2001. Variation on molecular species of polar lipids from Thermoplasma acidophilum depends on growth temperature. Lipids 36:103-105.

Valentine, D.L. 2007. Adaptations to energy stress dictate the ecology and evolution of the Archaea. Nature Reviews Microbiology 5: 316-323.

van der MaArel, M.J.E.C., Artz, R.R.E., HaAnstra, R. \& Forney, L.J. 1998. Association of marine archaea with the digestive tracts of two marine fish species. FEMS Microbiology Letters 173:189-194.

VAn de Vossenberg, J.L.C.M., Driessen, A.J.M. \& Konings, W.N. 1998. The essence of being extremophilic: the role of the unique archaeal membrane lipids. Extremophiles 2:163170.

Wakeham, S.G., Hopmans, E.C., Schouten, S. \& Sinninghe DAmSTÉ, J.S. 2004. Archaeal lipids and anaerobic oxidation of methane in euxinic water columns: a comparative study of the Black Sea and Cariaco Basin. Chemical Geology 205:427-442.

Wakeham, S.G., Amann, R., Freeman, K.H., Hopmans, E.C., JØrgensen, B.B., Putnam, I.F., Schouten, S., Sinninghe Damsté, J.S., Talbot, H.M. \& Woebken, D. 2007. Microbial ecology of the stratified water column of the Black Sea as revealed by a comprehensive biomarker study. Organic Geochemistry 38:20170-2097.

Wakeham, S.G., Turich, C.,Schubotz, F., Podlaska, P., Li, X.L., Varela, R., Astor, Y.,Sáenz, J.P., Rush, D., Sinninghe Damsté, J.S., Summons, R.E., Scranton, M., Taylor, G.T. \& Hinrichs, K.U. 2012. Biomarkers, chemistry and microbiology show chemoautotrophy in a multilayer chemocline in the Cariaco Basin. Deep-Sea Research I 63:133-156.

WARD, D.M., BRASSELl, S.C. \& EgLinton, G. 1985. Archaebacterial lipids in hot-spring microbial mats. Nature 318:656-659.

Weijers, J.W.H., Schouten, S., Hopmans, E.C., Geenevasen, J.A.J., David, O.R.P., Coleman, J.M., Pancost, R.D. \& Sinninghe DAmstÉ, J.S. 2006. Membrane lipids of mesophilic anaerobic bacteria thriving in peats have typical archaeal traits. Environmental Microbiology 8:648-657.

Weijers, J.W.H., Schouten, S., van den Donker, J.C., Hopmans, E.C. \&

SinNinghe Damsté, J.S. 2007. Environmental controls on bacterial tetraether membrane lipid distribution in soils. Geochimica et Cosmochimica Acta 71:703-713.
Weijers, J.W.H., Lima, K.H.L., Aquilina, A., Sinninghe Damsté, J.S. \& Pancost, R.D. 2011. Biogeochemical controls on glycerol dialkyl glycerol tetraether lipid distributions in sediments characterized by diffusive methane flux. Geochemistry Geophysics Geosystems 12:Q10010. http:// dx.doi.org/10.1029/.

Woese, C.R., Magrum, L.J. \& Fox, G.E. 1978. Archaebacteria. Journal of Molecular Evolution 11:245-252.

Wuchter, C., Schouten, S., Coolen, M.J.L. \& Sinninghe DAmsté, J.S. 2004. Temperature dependent variation in the distribution of tetraether membrane lipids of marine Crenarchaeota: implications for TEX paleothermometry. Paleoceanography 19: PA4028 doi:10.1029/2004PA001041.

Wuchter, C., Schouten, S., Wakeham, S.G. \& Sinninghe Damsté, J.S. 2005. Temporal and spatial variation in tetraether membrane lipids of marine Crenarchaeota in particulate organic matter: Implications for $\mathrm{TEX}_{86}$ paleothermometry, Paleoceanography 20:PA3013.

Wuchter, C.W. 2006. Ecology and Membrane Lipid Distribution of Marine Crenarchaeota: Implications for $\mathrm{TEX}_{86}$ Paleothermometry. PhD Thesis, University of Utrecht.

Wuchter, C.W., Schouten, S. \& Wakeham, S.G. 2006. Archaeal tetraether membrane lipid fluxes in the northeastern Pacific and the Arabian Sea: Implications for TEX86 paleothermometry. Paleoceanography 21:PA4208, doi:10.1029/2006PA001279.

XIE, S. 2013. Organic Geochemical Studies of Microbial Lipids and Carbon Flow in Oxygen-Deficient Marine Environments. $\mathrm{PhD}$ thesis, University of Bremen, Germany.

Yamamoto, M., Shimamoto, A., Fukuhara, T., Tanaka, Y. \& IsHIZAKA, J. 2012. Glycerol dialkyl glycerol tetraethers and TEX $_{86}$ index in sinking particles in the western North Pacific. Organic Geochemistry 53:52-62.

Zhang, Y.G., Zhang, C.L., Liu, X.L., Li, L., Hinrichs, K.U. \& NoAKES, J.E. 2011. Methane Index: a tetraether archaeal lipid biomarker indicator for detecting the instability of marine gas hydrates. Earth and Planetary Science Letters 307:525-534.

Zhou, H.D., Hu, J.F., Ming, L.L., Peng, P.A. \& Zhang, E. 2011. Branched glycerol dialkyl glycerol tetraethers and paleoenvironmental reconstruction in Zoigê peat sediments during the last 150 years. Chinese Science Bulletin 56: 2456-2463.

Recibido: 07.07.14

Aceptado: 20.10.14 